\title{
Cloud and Aerosol Properties, Precipitable Water, and Profiles of Temperature and Water Vapor from MODIS
}

Michael D. King, W. Paul Menzel, Yoram J. Kaufman, Didier Tanré, Bo-Cai Gao, Steven Platnick, Steven A. Ackerman, Lorraine A. Remer, Robert Pincus, and Paul A. Hubanks

IEEE Transactions on Geoscience and Remote Sensing

Manuscript submitted May 2, 2002, in final form October 13, 2002.

M. D. King, Y. J. Kaufman, and L. A. Remer are with the Earth Sciences Directorate, NASA Goddard Space Flight Center, Greenbelt, MD 20771 USA (email: king@climate.gsfc.nasa.gov).

W. P. Menzel is with NOAA/NESDIS, University of Wisconsin, Madison, WI 53706 USA.

D. Tanré is with the Laboratoire d'Optique Atmosphérique, Université des 
Sciences et Technologies de Lille, Villeneuve d'Ascq, France.

B. C. Gao is with the Naval Research Laboratory, Washington, DC 20375 USA.

S. Platnick is with the Joint Center for Earth Systems Technology, University of Maryland Baltimore County, Baltimore, MD 21228-5398 USA.

S. A. Ackerman is with the Dept. of Atmospheric and Oceanic Sciences, University of Wisconsin, Madison, WI 53706 USA.

R. Pincus is with NOAA-CIRES Climate Diagnostics Center, Boulder, CO 80309-0216 USA.

P. A. Hubanks is with Science Systems and Applications, Inc., Seabrook, MD 20706 USA. 
Abstract-The Moderate Resolution Imaging Spectroradiometer (MODIS) is an earth-viewing sensor that flies on the Earth Observing System (EOS) Terra and Aqua satellites, launched in 1999 and 2002, respectively. MODIS scans a swath width of $2330 \mathrm{~km}$ that is sufficiently wide to provide nearly complete global coverage every two days from a polar-orbiting, sun-synchronous, platform at an altitude of $705 \mathrm{~km}$. MODIS provides images in 36 spectral bands between 0.415 and $14.235 \mu \mathrm{m}$ with spatial resolutions of $250 \mathrm{~m}$ ( 2 bands), $500 \mathrm{~m}$ (5 bands) and $1000 \mathrm{~m}$ ( 29 bands). These bands have been carefully selected to enable advanced studies of land, ocean, and atmospheric properties. Twenty-six bands are used to derive atmospheric properties such as cloud mask, atmospheric profiles, aerosol properties, total precipitable water, and cloud properties. In this paper we describe each of these atmospheric data products, including characteristics of each of these products such as file size, spatial resolution used in producing the product, and data availability. 


\section{INTRODUCTION}

The Moderate Resolution Imaging Spectroradiometer (MODIS) is an EOS facility instrument that is currently flying aboard the Terra and Aqua spacecraft. It is especially well suited to global monitoring of atmospheric properties from space, and is based on heritage sensors such as the Advanced Very High Resolution Radiometer (AVHRR), Landsat Thematic Mapper (TM), High-resolution Infrared Radiation Sounder (HIRS), and the Nimbus-7 Coastal Zone Color Scanner (CZCS). The wide spectral range $(0.41-14.24 \mu \mathrm{m})$, frequent global coverage (one to two days revisit), and two high spatial resolution bands $(250 \mathrm{~m})$, permit state of the art global monitoring of atmospheric profiles, column water vapor amount, aerosol particles, and the subsequently formed clouds [10]. Barnes et al. [2] provide a detailed description of MODIS, including its performance attributes, optical design, spectral band characteristics, primary purpose of each band, pixel size, and signal-to-noise ratios at specified radiance levels, information that is essential for an in-depth understanding of the onboard calibrators and the operation of this highly sophisticated sensor.

The intent of this paper is to provide brief descriptions of each of the MODIS atmosphere data products that are being produced by the Terra mission and to describe differences, where they occur, with comparable products to be produced by Aqua. MODIS data are processed into various processing levels from Level-1 (radiances and brightness temperatures that have been geolocated), to Level-2 (derived geophysical data products at the same resolution and location as the Level-1 data) to Level-3 (variables mapped onto uniform space-time grid scales). In this paper we describe the essential elements of all Level-2 'pixelbased' MODIS atmosphere data products, and give examples of selected parameters in each product. Finally, we describe the MODIS Level-3 atmospheric prod- 
ucts that are produced at daily, eight-day, and monthly time intervals on a global $1^{\circ} \times 1^{\circ}$ latitude-longitude grid. In addition to simple statistics (mean, standard deviation, etc.) computed for each parameter, the Level-3 products also contain marginal density and joint probability density functions between selected parameters.

\section{THE MODIS ATMOSPHERE DATA PROCESSING SYSTEM}

Terra and Aqua data are stored on the spacecraft in solid-state memory and periodically transmitted to the ground. Once on the ground, these data are separated into instrument packets 2 hours in length and sent to the Goddard Space Flight Center for further processing. Fig. 1 shows the data processing architecture and data products that are used in processing MODIS atmospheric properties (adapted from [20]). The first step is to produce Level-1A (MOD01) data that consist of counts for all 36 bands of MODIS, along with raw instrument engineering and spacecraft ephemeris data. This data product is separated into 5 minute granules, and hence all Level-1B, geolocated, and subsequently processed pixel-level data are processed into 5 minute granules $(\sim 2000 \mathrm{~km}$ in length along the orbital track), producing some 244 granules (or files) per day per data product.

Following Level-1A, calibration is applied using the onboard calibrators, space looks, and instrument performance data, and these Level-1B (MOD02) data are stored in 3 separate files, one each for 250, 500, and $1000 \mathrm{~m}$ bands. Since many algorithms that follow in the subsequent processing chain require a combination of spectral bands having inherently different spatial resolutions, a Level-

$1 \mathrm{~B}$ product is produced at $250 \mathrm{~m}$ resolution (daytime, 2 bands), $500 \mathrm{~m}$ (daytime, 5 bands plus two $250 \mathrm{~m}$ bands aggregated to equivalent $500 \mathrm{~m}$ bands), and $1000 \mathrm{~m}$ (daytime, 36 bands all at $1000 \mathrm{~m}$ or aggregated to that resolution from the finer 
resolution bands). At night, only the thermal bands are recorded so the MOD02 $1 \mathrm{~km}$ granules are smaller in size (17 bands) than during the daytime when all 36 bands are recorded. Geolocation of each pixel is also contained in the MOD02 file, but only every $5^{\text {th }}$ pixel and every $5^{\text {th }}$ scan line. For full resolution navigation, a separate geolocation (MOD03) data file is produced at a $1 \mathrm{~km}$ spatial resolution, containing geodetic coordinates, ground elevation, and viewing geometry.

All of the data products described in this paper are Level-2 and Level-3 products that ultimately require well calibrated and geolocated data from MOD02 and MOD03. These data products include the cloud mask (MOD35) for distinguishing clear sky from clouds, atmospheric profiles (MOD07), aerosol product (MOD04), precipitable water product (MOD05), cloud product (MOD06), and gridded time-averaged (Level-3) atmosphere products on a daily, eight-day, and monthly mean basis (MOD08 products). Table I lists the MODIS atmosphere data products, responsible investigators, processing level, product ID used in ordering data from the EOS data system, spatial resolution, file frequency, and file size. All of these data products are archived and distributed by the Goddard Distributed Active Archive Center (DAAC). Data products from Terra use the product ID MODxx, whereas those from Aqua use the product ID MYDxx (e.g., MYD06).

\section{CLOUD MASK}

The cloud mask (MOD35) algorithm classifies each pixel as either confident clear, probably clear, probably cloudy, or cloudy. The cloud mask consists of 48 bits of output that include information on individual cloud test results, the processing path, ancillary information (e.g., land/sea tag), and additional information (e.g., thin cirrus detected, heavy aerosol). The cloud mask algorithm [1] uses a 
series of threshold tests applied to 17 of the 36 MODIS bands to identify the presence of clouds in the instrument field-of-view. The specific tests executed are a function of surface type, including land, water, snow/ice, desert, and coastal, and are different during the day and night. Each cloud detection test returns a confidence level that the pixel is clear ranging in value from 1 (high confidence clear) to 0 (low confidence clear). Tests capable of detecting similar cloud conditions are grouped together and a minimum confidence is determined for each group. The final cloud mask is then determined from the product of the results from each group. This approach is clear-sky conservative in the sense that if any test is highly confident that the scene is cloudy, the final clear sky confidence is 0 . The first 8 bits of the cloud mask provide a summary adequate for many processing applications.

Fig. 2 shows an example of the cloud mask result for a daytime granule over Western Australia on June 5, 2001. The 'true color' image is a composite image of MODIS bands 1,4 and $3(0.645,0.555$, and $0.469 \mu \mathrm{m}$, respectively). The accompanying cloud mask image shows the final result of the cloud mask algorithm with confident clear (blue), probably clear (green), probably cloudy (yellow), and cloudy (white). Most of the region is flagged as confident clear or probably clear. Some of the land near the coast is flagged as probably clear while the true-color composite suggests the region to be clear. This results from a combination of thin cirrus, haze, and varying surface radiative properties. Experience gained in comparing the cloud mask results with collocated surface lidar systems suggest that the confident clear and probably clear designations are invariably clear, whereas the probably cloudy and cloudy designations are invariably cloudy, with the probably cloudy designation arising near the edge of clouds or where there is thin cirrus present in the atmosphere. Subsequent algorithms are given 
the results of the individual tests and may choose to use these to further determine whether to process the pixel, as different algorithms show different sensitivities to these cloud mask results.

\section{ATMOSPHERIC PROFILES}

The atmospheric profiles (MOD07) algorithm performs statistical retrievals of atmospheric temperature and moisture layers, total precipitable water, total column ozone, and stability indices. While MODIS is not per se a sounding instrument, the information content of the high spatial resolution infrared multispectral radiance observations can improve upon a priori definitions of atmospheric state by providing better delineation of horizontal gradients. The MODIS clear-sky retrievals are performed over land and ocean for both day and night when at least $20 \%$ of the radiances measured within a $5 \times 5$ field of view area (approximately $5 \mathrm{~km}$ resolution) are cloud-free. The retrieval methods employed here are partly based on the work of the International ATOVS (Advanced TIROS Operational Vertical Sounder) Processing Package (IAPP) [15] and the Geostationary Operational Environmental Satellite (GOES) sounder algorithms [16], [13], [14].

The operational MODIS atmospheric profile algorithm is a statistical regression. The algorithm uses 12 infrared bands with wavelengths between $4.47 \mu \mathrm{m}$ (band 24) and $14.24 \mu \mathrm{m}$ (band 36). Surface emissivity effects in the shortwave infrared bands are mitigated by regressing against band differences (e.g., instead of $T_{4.52}$ and $T_{4.47}$ we use the difference $T_{4.52}-T_{4.47}$ in the regression, where $T_{\lambda}$ represents brightness temperature at wavelength $\lambda$ ). An extension of the NOAA-88 data set containing more than 8400 global radiosonde profiles of temperature, moisture, and ozone is used to determine the regression coefficients. MODIS infrared band radiances are calculated from the radiosonde observations of the at- 
mospheric state, and the regression coefficients are generated from these calculated radiances/atmospheric profile pairs. The radiative transfer calculation of the MODIS spectral band radiances is performed using a transmittance model called the Pressure layer Fast Algorithm for Atmospheric Transmittances [4]; this model has 101 pressure level vertical coordinates from 0.05 to $1100 \mathrm{hPa}$. The calculations take into account the satellite zenith angle, absorption by well-mixed gases (including nitrogen, oxygen, and carbon dioxide), water vapor (including the water vapor continuum), methane, carbon monoxide, nitrogen dioxide, and ozone. In addition, MODIS instrument noise is added into the calculated spectral band radiances.

To perform the retrieval, the regression coefficients are applied to actual MODIS measurements to obtain the estimated atmospheric profiles, the integration of which yields the total precipitable water (TPW) ${ }^{1}$ or total column ozone. The advantage of this approach is that it does not need MODIS radiances collocated in time and space with atmospheric profile data, as it requires only historical profile observations. To address radiative transfer model uncertainties and residual instrument calibration anomalies, radiance bias adjustments are made in the retrieval algorithm; these are calculated seasonally from MODIS observed clear sky radiance composites and global model atmospheric analyses.

Fig. 3 shows the temperatures retrieved from the Terra-MODIS radiances on May 22, 2001 at $0500 \mathrm{UTC}$ at levels (a) $850 \mathrm{hPa}$. (b) $700 \mathrm{hPa}$, and (c) $500 \mathrm{hPa}$ over the Midwestern United States. At this time, the cold front associated with a lowpressure system centered in northern Wisconsin extended southward through

\footnotetext{
1 Atmospheric profile retrievals are saved at only 20 levels in the MOD07 data product; however, the integration to TPW is performed from the original retrieved profiles with 101 levels. Thus, integration of the 20 -level profiles will not necessarily result in the same value reported in the TPW field.
} 
Illinois, Missouri, and eastern Texas. The tongue of cool air behind this front can be seen pushing into the central and upper Midwest, and the pattern extends up through all three levels in the atmosphere shown.

Preliminary evaluation of the Aqua-MODIS atmospheric profiles algorithm (MYD07) indicates its performance is comparable to that of Terra. Fig. 4 shows one example from the Aqua infrared temperature and moisture retrievals. The total precipitable water (in $\mathrm{cm}$ ) from September 4, 2002 at 1750 UTC indicates a sharp moisture boundary along the east coast of the United States associated with the cold front of a low-pressure system in eastern Canada: The associated GOES-8 Sounder precipitable water shows general agreement, but it does not have the spatial resolution to capture the sharp moisture boundary. A crosssection drawn through the strongest moisture gradient highlights the vertical structure of this front. Moist air, with mixing ratios up to $15 \mathrm{~g} \mathrm{~kg}^{-1}$, exists through $700 \mathrm{hPa}$ to the south of the front, then the air dries out sharply around $38.4^{\circ}$ latitude. The vertical structure in the temperature field shows less structure than the moisture, and the temperature difference across the front is also less pronounced; however, warmer surface temperatures are evident at latitudes south of the front.

Comparisons of MODIS atmospheric products with other observations collocated in time and space are facilitated by specialized instrumentation at the Southern Great Plains (SGP) Atmospheric Radiation Measurement-Cloud and Radiation Testbed (ARM-CART) site in Oklahoma. Terra and Aqua each pass over the SGP CART site twice daily; radiosondes are launched three times each day; and observations of total column moisture are made by the microwave radiometer (MWR) every 40-60 sec. Additional comparisons are possible with the GOES-8 sounder [18], [19] that retrieves TPW hourly. Comparison for 17 months 
of Terra MODIS infrared TPW for 80 clear-sky cases from April 1 to September 1, 2002 with TPW from GOES-8 sounder, radiosondes, and MWR are presented in Fig. 5. These cases were chosen by manual inspection to exclude any scenes with cloud contamination and with MODIS sensor zenith angle $\theta>50^{\circ}$ at the CART site. MODIS shows general agreement with all three systems, the RMS difference between MODIS and MWR TPW is $4.7 \mathrm{~mm}$ (compared with $1.4 \mathrm{~mm}$ and 1.3 $\mathrm{mm}$ for GOES-8 and radiosondes, respectively). For dry atmospheres, MODIS overestimates the total column moisture; the average TPW bias (MODIS minus MWR) is approximately $3 \mathrm{~mm}$ for the 36 dry cases with TPW $\leq 17 \mathrm{~mm}$. On average for the 44 wet cases (TPW $>17 \mathrm{~mm}$ ), the MODIS regression-based TPW retrievals are drier than the MWR by $5.7 \mathrm{~mm}$. Thus MODIS will reduce the magnitude of a TPW gradient; nonetheless, MODIS will still capture the small-scale structure of spatial gradients across a front as well as the global changes from day to day.

MODIS is producing global fields of temperature, moisture, and ozone. The primary value of these fields lies in the depiction of fine scale horizontal gradients. When combined with the increased atmospheric profiling capability of high spectral resolution infrared systems (such as the Atmospheric Infrared Sounder, AIRS), the MODIS offers improved sounding performance in cloudy conditions (by identifying sub AIRS field-of-view cloudiness) and delineates spatial gradients beyond the AIRS instrument resolution.

\section{AEROSOL PRODUCT}

The aerosol product (MOD04) is based on different algorithms for the remote sensing of tropospheric aerosol over land [9] and ocean [25]. Both algorithms try to match MODIS observed reflectances to a lookup table of pre-computed reflectances for a wide variety of commonly observed aerosol conditions, as summa- 
rized by King et al. [11]. Over land, the prime difficulty is separating the reflectance measured by the satellite into an atmospheric part and a land surface part. This difficulty is overcome by estimating the visible surface reflectance from the MODIS-measured reflectance in the shortwave infrared wavelength $(2.13 \mu \mathrm{m})$ for dark targets, as described by Kaufman et al. [9]. Removing the estimated surface reflectance from the total measured by the satellite, the atmospheric contribution is isolated by using lookup tables to determine the aerosol characteristics and optical thickness in the scene. Final land products include aerosol optical thickness $\left(\tau_{\mathrm{a}}\right)$ at $0.47,0.56$ and $0.65 \mu \mathrm{m}$ at a $10 \mathrm{~km}$ spatial resolution. The spectral dependence of the reflectance across the visible wavelengths is then used to obtain a rough estimate of the fine mode (radius $<0.6 \mu \mathrm{m}$ ) fraction of the aerosol optical thickness at $0: 56 \mu \mathrm{m}$.

The ocean algorithm assumes that the surface reflectance contribution to the total reflectance is small and can be calculated from geometry and assumptions about the sea state [25]. The better-characterized ocean surface permits the use of reflectances at 6 wavelengths $(0.56-2.13 \mu \mathrm{m})$ in the derivation. Again, the retrieved aerosol products are represented by the best fits between observed reflectance and the lookup table. Ocean products include aerosol optical thickness at $0.47,0.56,0.65,0.86,1.24,1.64$, and $2.13 \mu \mathrm{m}$ at a $10 \mathrm{~km}$ spatial resolution. Using a wide spectral range over ocean allows the derivation of the effective radius of the particle population, and more accurate determination of fine mode fraction than over land. The aerosol algorithm is applied to cloud free conditions outside the sunglint region (glint angle $<40^{\circ}$ ) and for land surface reflectance at $2.13 \mu \mathrm{m}<$ 0.25 at nadir and 0.4 at slant view directions. The comparison with the lookup table is performed for the average of the $25 \%-75 \%$ pixels over the ocean and $20 \%$ $50 \%$ over the land in order to avoid any undetected non-aerosol contamination. 
A minimum of $10(12)$ pixels is required for the analysis in any $10 \mathrm{~km}$ region over ocean (land).

Fig. 6 shows a multispectral "true-color" composite image, associated retrieved $\tau_{a}(0.56 \mu \mathrm{m})$, fraction of fine mode aerosol to total optical thickness $\left(\tau_{\mathrm{f}} / \tau_{\mathrm{a}}\right)$ at $0.56 \mu \mathrm{m}$, and aerosol effective radius for one granule at 16:25 UTC on May 4, 2001. This granule, located over the east coast of the United States, displays consistency between the entirely independent land and ocean retrievals. Areas where the aerosol optical thickness cannot be retrieved due to the presence of clouds or sunglint are colored gray in Fig. 6b. Aerosol effective radius, shown in Fig. 6d, is only derived over oceans. The retrieval in this granule shows the aerosol over land and near-shore coastal region to be dominated by fine mode aerosols with an effective radius $\sim 0.2 \mu \mathrm{m}$, typical of pollution episodes in this region [22]. Further from land the pollution gradually gives way to larger aerosol, possibly a mixture with sea salt. The accuracy of satellite estimates of aerosol optical thickness was first suggested based on theoretical analyses [9], [25], and consisted of a bias of \pm 0.05 over land and \pm 0.03 over ocean due to uncertainty in the estimate of surface reflectance, and $\pm 0.20 \tau_{\mathrm{a}}$ over land and $\pm 0.05 \tau_{\mathrm{a}}$ over ocean due to uncertainty in the aerosol absorption and scattering phase function. The apparently low uncertainty over ocean results from the use of the wide spectral range of MODIS to derive the aerosol size distribution.

A number of papers describe the validation of MODIS aerosol products, primarily using the operational Aerosol Robotic Network (AERONET) sunphotometers [6]. Over land, Chu et al. [3] confirm the visible $\tau_{\mathrm{a}}$ accuracy of $\Delta \tau_{\mathrm{a}}=$ $\pm 0.20 \tau_{\mathrm{a}} \pm 0.05$ and a reasonable spectral correlation. Over ocean in non-dusty regimes, Remer et al. [23] confirm that MODIS retrieves $\tau_{\mathrm{a}}$ with an accuracy $\Delta \tau_{\mathrm{a}}=$ $\pm 0.03 \tau_{\mathrm{a}} \pm 0.05$, and particle effective radius within an accuracy of $\pm 0.10 \mu \mathrm{m}$. In an 
oceanic dusty regime, Levy et al. [12] show similar $\tau_{\mathrm{a}}$ errors in the mid-visible wavelengths, but less accuracy in determining particle radius, presumably due to nonsphericity effects that are not yet accounted for in the lookup tables.

For Aqua-MODIS, the operational algorithm is the same as it is for TerraMODIS. For both Terra and Aqua, improvements have been introduced for addressing a few key issues. Over land, the reliance on dark targets has been relaxed so that aerosol retrievals will be possible over a larger land surface area having a reflectance at $2.13 \mu \mathrm{m}$ up to 0.4 , as described earlier. This became possible due to analysis of aircraft data on the spectral properties of land surfaces from desert and non-desert regions [7] and successful application to MODIS data [Eric Vermote, personal communication]. Over ocean, an improved cirrus detection technique [5] has been implemented, which combines cold cloud masking, spatial coherence tests [17], and a new high cloud mask test based on the $1.38 \mu \mathrm{m}$ band.

\section{TOTAL PRECIPITABLE WATER PRODUCT}

MODIS has five near-infrared bands located within and around the $0.94 \mu \mathrm{m}$ water vapor band for remote sensing of column water vapor amounts over clear land areas and over oceanic areas with sunglint. The retrieval algorithm [8], [10] relies on observations of water vapor absorption of near-infrared solar radiation reflected by the bottom surface. The algorithm uses ratios of water vapor absorbing bands (within the $0.94 \mu \mathrm{m}$ water vapor band) with atmospheric window bands at 0.86 and $1.24 \mu \mathrm{m}$. The ratios largely remove the effects of variation of surface reflectance with wavelength for most land surfaces and result in the atmospheric water vapor transmittances. The column water vapor amount is derived from the transmittance using a table lookup procedure and applied to every $1 \mathrm{~km}$ pixel. The lookup tables were pre-calculated using a line-by-line at- 
mospheric transmittance code and the HITRAN2000 spectroscopic database [24]. Water vapor values using the near-infrared algorithm can be determined with errors of about $7 \%$ based on comparisons with water vapor measurements using ground-based microwave radiometers. Systematic errors in the derived water vapor values can be further reduced if the water vapor line parameters are improved in the future.

Fig. 7 shows a multispectral image of one Terra-MODIS granule acquired over the Eastern United States at 1705 UTC on June 24, 2002. Panel (a) shows a false color composite constructed from bands at $0.645,0.0 .858$, and $0.469 \mu \mathrm{m}$. On this day, there was a strong gradient between moist air in the southeastern U.S. and a band of dry air extending from central Texas through eastern Nebraska and into southern Wisconsin. An upper-level low centered over Louisiana is associated with the moist air throughout the southeastern United States at this time. The sharp boundary between this warm, moist air and the narrow streak of dry air coincides with a strong jet at $850 \mathrm{hPa}$ that is transporting dry continental air northward. High-resolution total precipitable water retrievals from MODIS can be useful in anticipating the distribution of precipitation patterns. At 0000 UTC on June 25, 2002, seven hours after the MODIS overpass, rain was reported on either side of the dry line. Some precipitation was falling throughout the southeastern U.S., including thunderstorms in Illinois and Arkansas; heavy rain was falling in northwestern Wisconsin and Minnesota. A distinct region without precipitation existed along the axis of the band of low TPW observed by MODIS.

The near-infrared TPW (Fig. 7b) and the thermal infrared TPW (Fig. 7c) both depict the strong moisture gradient very well. The $5 \mathrm{~km}$ IR TPW tends to smooth the moisture gradient and is not generating retrievals in the thin and broken 
clouds. From the green color of the false color image, it is readily apparent that the surface reflectance is evident throughout the thin and broken cloud regions of the Gulf States, enabling selected clear sky retrievals to be obtained with this technique using the $1 \mathrm{~km}$ near-infrared bands. The near-infrared and thermal infrared TPW retrievals tend to corroborate each other; each provides unique coverage with the near-infrared $1 \mathrm{~km}$ product providing TPW details over land and sunglint regions of the ocean during the day and the thermal infrared $5 \mathrm{~km}$ product providing TPW over land and ocean during both day and night under clear skies. The near-infrared TPW includes a quality assurance parameter that indicates whether the pixel is clear or cloudy, and this cloud mask is somewhat different than the cloud mask used to filter the clear-sky in the thermal infrared algorithm. This accounts for some of the differences in coverage of the nearinfrared and thermal infrared precipitable water parameters in Fig. 7.

\section{CLOUd PRODUCT}

The cloud product (MOD06) algorithm combines infrared and visible techniques to determine the physical, radiative, and microphysical properties of clouds [21]. Cloud optical thickness and effective radius are derived globally using 6 visible and near-infrared bands at $1 \mathrm{~km}$ spatial resolution. Cloud top properties, including cloud top temperature, cloud top pressure, and effective emissivity, are derived using the infrared split window and longwave $\mathrm{CO}_{2}$ absorption bands (both day and night) at $5 \mathrm{~km}$ spatial resolution. Cloud thermodynamic phase is computed at $5 \mathrm{~km}$ resolution using a two-band algorithm that includes an additional thermal band at $8.55 \mu \mathrm{m}$, and also at $1 \mathrm{~km}$ resolution using a different technique based on results from the cloud mask decision tree followed by a bispectral threshold test, shortwave infrared tests, and finally cloud top temperature [21]. Finally, the cloud product contains a cirrus reflectance 
product at a visible wavelength for use in removing cirrus scattering effects from the land surface, and it utilizes an additional band at $1.38 \mu \mathrm{m}$. Hence, the cloud product contains many different cloud properties derived from 14 bands in total, and the file size is different during the night (only cloud top properties and thermodynamic phase at $5 \mathrm{~km}$ resolution) than during the day (when additional $1 \mathrm{~km}$ resolution products are included), as outlined in Table I.

Fig. 8 shows an example of the cloud optical thickness, cloud top pressure, and effective radius for a daytime granule of Terra-MODIS data over the Western Pacific Ocean near the Kamchatka Peninsula on August 10, 2001 at 00:25 UTC. The true color image in (a) shows extensive cloud cover over the Sea of Okhotsk, including mid-level and upper-level ice clouds, whereas the Bering Sea to the east of the Peninsula contains extensive marine stratocumulus clouds with numerous ship tracks in the southeastern portion of the image. The accompanying images show the (b) cloud optical thickness, (c) cloud top pressure, and (c) cloud effective radius, where we have used a different color scale for water and ice clouds in (b) and (d). The optically thick marine stratocumulus to the east of the Peninsula are identified as water clouds with optical thicknesses $\tau_{c}(0.65 \mu \mathrm{m})$ up to $\sim 25$. The optically thick ice clouds over the Sea of Okhotsk and around the southern portion of the Kamchatka Peninsula have cloud optical thicknesses approaching 40 . The ship tracks are not easily identified in the cloud optical thickness image shown here, but they result in reduced effective radii in the microphysical retrievals shown in (d). For this scene, the thermal infrared and decision tree algorithms for deriving cloud thermodynamic phase, discussed by Platnick et al [21], are in quite good agreement. Finally, the cloud top pressure for the cloud-filled pixels, shown in (c), clearly show that the water clouds lie predominantly between 700 and $850 \mathrm{hPa}$, whereas the optically thick ice clouds over 
the Sea of Okhotsk lie at altitudes above the $500 \mathrm{hPa}$ level.

\section{LEVEL-3 ATMOSPHERE PRODUCTS}

There are three Level-3 atmosphere products (MOD08), each covering a different time interval (daily, 8-day, and monthly), that contain statistics derived from four Level-2 atmosphere products: aerosol (MOD04), precipitable water (MOD05), cloud (MOD06), and atmospheric profiles (MOD07). Statistics are sorted into $1^{\circ} \times 1^{\circ}$ cells on an equal-angle global grid $(180 \times 360$ cells $)$.

The daily product contains roughly 600 statistical datasets that are derived from approximately 80 scientific parameters from the four Level-2 products noted above. The 8-day and monthly products, identical in format, are somewhat larger in size than the daily product, comprising roughly 800 statistical datasets.

For the daily product, any Level-2 granule that overlaps any part of the data day ( 0000 to 2400 UTC) is included in the computation of the statistics. Therefore, a particular Level-2 granule may be included in two consecutive MOD08 daily products. The 8-day product is computed by manipulating and summarizing the daily product over eight consecutive days (half the 16-day repeat time of the Terra and Aqua orbits). The running 8-day intervals are reset at the beginning of each year (January 1), in concert with comparable Level-3 products produced by the oceans and land discipline groups of MODIS. The monthly product is computed by manipulating and summarizing the daily product over a calendar month.

There is no separation of MODIS science parameters by orbit (ascending/descending) node; however there is a day/night separation and/or process/no process decision for a number of parameters at both Level-2 and Level-3. All of the aerosol (MOD04) and near-infrared water vapor (MOD05) parameters, as well as the cirrus detection and cloud optical parameters (both a subset of 
MOD06) are only processed for daytime (sunlit) granules. Cloud top properties (a subset of MOD06) are processed for both day and night; and are separated in Level-3 by daytime only, nighttime only, or combined day and night. Atmosphere profiles (MOD07) are also processed for both day and night; but are not separated in the Level-3 product.

The set of statistical summaries computed for each parameter depends on the parameter being considered and might include: (i) simple statistics (mean, minimum, maximum, standard deviation), (ii) parameters of normal and lognormal distributions, (iii) fraction of pixels that satisfy some condition (e.g., cloudy or clear), (iv) histograms of the distribution within each grid box, (v) histograms of the confidence placed in each measurement, and (vi) histograms and/or regressions derived from comparing one science parameter to another. Level-3 statistics may be computed for a subset of Level-2 pixels that satisfy some condition (e.g., water clouds or ice clouds). Finally, Level-3 statistics are computed by sub-sampling the Level-2 data at the resolution of the internal Level-2 (input file) geolocation. For example, since the geolocation internal to the MOD06 cloud product is $5 \mathrm{~km}$, every MOD08 statistic derived from MOD06 (including the Quality Assurance parameters) is computed from a set of Level-2 pixels sub-sampled at that resolution (about 480 pixels instead of the $12,0001 \mathrm{~km}$ pixels that actually fall within the $1^{\circ} \times 1^{\circ}$ cell).

In addition, histograms, joint histograms, and/or regressions derived from comparing one science parameter to another, are often computed for a subset of observations that satisfy some condition (e.g., liquid water clouds only, ice clouds only, etc.). The thirteen joint histograms defined in the Level-3 atmosphere product (MOD08) are summarized in Table II. All joint histograms are derived from the cloud product (MOD06), ten of which are aggregated (separated) 
by cloud phase (liquid water or ice). This group of joint histograms in computed from the parameters (i) cloud optical thickness, (ii) cloud effective particle radius, (iii) cloud top temperature, and (iv) cloud effective emissivity. In MOD08 there are five joint histograms produced for liquid water clouds and five for ice clouds, all during the daytime. The numerical boundaries used to bin the data vary by cloud retrieval phase, as summarized in Table II. The remaining three joint histograms are aggregated (separated) by day / night mode (daytime, nighttime, and combined day and night), and are computed from the parameters (v) cloud top pressure and (vi) cloud effective emissivity (cf. Table II).

Although for a few parameters the set of predetermined statistics changed once (or perhaps twice) during the first $2^{1 / 2}$ years of MODIS data collection [Collection 001 (beta) and Collection 003 (provisional)], the intent was to create an unbroken record of fixed (unchanging) Level-3 statistical summaries, unique to each science parameter. For Collection 004, the first completely validated set of MODIS science data, the set of statistical summaries created for each science parameter will be fixed and unchanging. MODIS Collection 004 processing is slated to begin on October 29, 2002, where both a forward stream, as well as a reprocessing stream going back to year 2000 , will be produced. This will eventually create a multiyear validated set of MODIS science data and a fixed set of global statistics.

Fig. 9 shows monthly mean values of (a) cloud optical thickness, (b) aerosol optical thickness, and (c) precipitable water derived from the near-infrared algorithm over land and sunglint, for August 2001. The cloud optical thickness image is a combination of liquid water and ice cloud retrievals, and clearly shows greater optical thickness along the intertropical convergence zone as well as at high latitudes in the northern and southern hemispheres. Fig. $9 \mathrm{~b}$ shows the 
monthly mean aerosol optical thickness over both land and ocean, except for locations where the surface is too bright to be able to retrieve the aerosol loading (e.g., Sahara, Saudi Arabian, and Kalahari deserts, Tibetan plateau). During August the biomass burning in Angola, Zambia, and the Congo are quite striking, as are industrial emissions off China and the Indian subcontinent. In 2001 the burning season in South America was late in starting, so August is not as distinctive as later in September when the biomass burning season was in full swing. The precipitable water retrievals in Fig. 9c are derived over land and sunglint regions of the cloud-free ocean during the daytime using the nearinfrared algorithm. During August there was no sunglint over the oceans for the Terra orbit at latitudes south of $23^{\circ} \mathrm{S}$, hence no water vapor retrievals over the southern ocean. The large water vapor concentration in the tropics and humid sections of the southeastern United States and the Indian subcontinent are readily apparent. This figure compares favorably with the thermal infrared-derived precipitable water (not shown) that is derived over all cloud-free pixels during both day and night.

These displays are the equal-area (Hammer-Aitoff) projection, which are available for viewing on the MODIS atmosphere web site (modis-atmos. gsfc.nasa.gov) along with other time periods, parameters, and statistics of interest. It should be noted that the web site contains Level- 3 images on both the native equal-angle grid as well as an equal-area grid, even though the Level-3 product contains global statistical summaries on only the equal-angle grid.

In addition to mean values of various parameters, the Level-3 product contains additional statistical properties including joint histograms of selected variables, as discussed above. Fig. 10 shows a joint histogram of cloud optical thickness and effective radius for liquid water clouds over ocean for a region off the 
Chile and Peru coast bounded by $12^{\circ}-24^{\circ} \mathrm{S}$ and $68^{\circ}-80^{\circ} \mathrm{W}$ for the month of August 2001. Histograms such as this are contained within the Level-3 file for all $1^{\circ} \times 1^{\circ}$ cells globally, and are aggregated for water clouds and ice clouds separately. Note the dominance of effective radii in the range of 9-14 $\mu \mathrm{m}$, which are reasonable values for the boundary layer marine stratocumulus clouds prevalent in this region. The bin boundaries of the aggregated histogram are also shown in this figure.

\section{SUMMARY AND CONCLUSIONS}

In this paper we have described each of the MODIS atmosphere data products, including the frequency and size of each file, and have given examples of each of these data products based on observations from the Terra and, in some cases, Aqua spacecraft. Aqua carries a similar MODIS instrument to Terra's, but in a 1:30 pm ascending sun-synchronous polar orbit, rather than the 10:30 am descending orbit of Terra. The same data products are produced from Aqua as from Terra, thus enabling studies of diurnal variability of cloud, aerosol, and water vapor properties. Due to differences in the performance of individual detectors, cross talk, and gain settings, there are some subtle and not so subtle differences in several of the data products. Of particular significance is the known failure of many of the individual detectors in the $1.64 \mu \mathrm{m}$ spectral band that makes it impossible to retrieve cloud effective radius using this band. Otherwise, preliminary examination of the Aqua products shows a similar accuracy to the Terra data products. Therefore, the experience in the precise characterization of the MODIS spectral bands on Terra that was achieved after the first year of operation yielded similar precision on the Aqua spacecraft after only 3 months in orbit. The location of sunglint is considerably different in the afternoon orbit, so the areas of the ocean that are impossible to retrieve water vapor concentration 
from using the near-infrared bands (like the southern oceans during August 2001, as shown in Fig. 9c) will now move to the northern hemisphere. Hence, between Terra and Aqua it should be possible to obtain high spatial resolution precipitable water vapor concentrations globally.

All data produced by the algorithms described in this paper are available from the Goddard Distributed Active Archive Center, and may be ordered via the EOSDIS Data Gateway (redhook.gsfc.nasa.gov/ imswww/pub/imswelcome) or Terra WHOM (daac.gsfc.nasa.gov/data). Quicklook images of all Level-1B true color and Level-3 data products are available from the MODIS atmosphere web site at modis-atmos.gsfc.nasa.gov. In addition, this site contains (i) software tools for locating granules, doing spatial subsetting, and visualizing various scientific data sets, (ii) extensive references and descriptions of the algorithms used to process the data, and (iii) calendars of data availability.

\section{ACKNOWLEDGMENTS}

The authors are grateful to E. G. Moody, M. A. Gray, R. A. Frey, L. E. Gumley, S. Matoo, R. R. Li, X. Liang, B. A. Baum, J. C. Riédi, S. W. Seemann, J. Li, and R. Hucek for software engineering, design, visualization, testing, and implementation of the MODIS atmosphere algorithms described in this paper. 


\section{REFERENCES}

[1] S. A. Ackerman, K. I. Strabala, W. P. Menzel, R. A. Frey, C. C. Moeller, and L. E. Gumley, "Discriminating clear sky from clouds with MODIS," J. Geophys. Res., vol. 103, pp. 32141-32157, 1998.

[2] W. L. Barnes, T. S. Pagano, and V. V. Salomonson, "Prelaunch characteristics of the Moderate Resolution Imaging Spectroradiometer (MODIS) on EOS-AM1," IEEE Trans. Geosci. Remote Sens., vol. 36, pp. 1088-1100, 1998.

[3] D. A. Chu, Y. J. Kaufman, C. Ichoku, L. A. Remer, D. Tanré, and B. N. Holben, "Validation of MODIS aerosol optical depth retrieval over land" Geophys. Res. Lett., vol. 29, no.12, DOI 10.1029/2001GL013205, 2002.

[4] S. Hannon, L. L. Strow, and W. W. McMillan, "Atmospheric infrared fast transmittance models: A comparison of two approaches," Proc. SPIE Conf. 2830, Optical Spectrosc. Techniques and Instrumentation for Atmos. and Space Res. II, 1996.

[5] B. C. Gao, Y. J. Kaufman, D. Tanré, and R. R. Li, "Distinguishing tropospheric aerosols from thin cirrrus clouds for improved aerosol retrievals using the ratio of $1.38-\mu \mathrm{m}$ and $1.24 \mu \mathrm{m}$ channels," Geophys. Res. Lett., in press, 2002.

[6] B. N. Holben, T. F. Eck, I. Slutsker, D. Tanré, J. P. Buis, A. Setzer, E. Vermote, J. A. Reagan, Y. J. Kaufman, T. Nakajima, F. Lavenu, I. Jankowiak, and A. Smirnov, "AERONET-A federated instrument network and data archive for aerosol characterization," Remote Sens. Environ., vol. 66, pp. 1-16, 1998.

[7] A. Karnieli, Y. J. Kaufman, L. Remer, and A. Wald, "AFRI-Aerosol free vegetation index," Remote Sens. Environ., vol. 77, pp. 10-21, 2001.

[8] Y. J. Kaufman and B. C. Gao, "Remote sensing of water vapor in the near IR 
from EOS/MODIS," IEEE Trans. Geosci. Remote Sens., vol. 30, pp. 871-884, 1992.

[9] Y. J. Kaufman, D. Tanré, L. A. Remer, E. F. Vermote, A. Chu, and B. N. Holben, "Operational remote sensing of tropospheric aerosol over land from EOS Moderate Resolution Imaging Spectroradiometer," J. Geophys. Res., vol. 102, pp. 17051-17067, 1997.

[10] M. D. King, Y. J. Kaufman, W. P. Menzel, and D. Tanré, "Remote sensing of cloud, aerosol, and water vapor properties from the Moderate Resolution Imaging Spectrometer (MODIS)," IEEE Trans. Geosci. Remote Sens., vol. 30, pp. 2-27, 1992.

[11] M. D. King, Y. J. Kaufman, D. Tanré, and T. Nakajima, "Remote sensing of tropospheric aerosols from space: Past, present, and future," Bull. Amer. Meteor. Soc., vol. 80, pp. 2229-2259, 1999.

[12] R. C. Levy, L. A. Remer, D. Tanré, Y. J. Kaufman, C. Ichoku, B. N. Holben, J. M. Livingston, P. B. Russell, and H. Maring, “Evaluation of the MODIS retrievals of dust aerosol over the ocean during PRIDE," J. Geophys. Res., in press, 2002.

[13] J. Li, and H. L. Huang, "Retrieval of atmospheric profiles from satellite sounder measurements by use of the discrepancy principle," Appl. Opt., vol. 38, 916-923, 1999.

[14] J. Li, C. C. Schmidt, J. P. Nelson, T. J. Schmit, and W. P. Menzel, "Estimation of total atmospheric ozone from GOES sounder radiances with high temporal resolution," J. Atmos. Oceanic Technol., vol. 2, 157-168, 2001.

[15] J. Li, W. W. Wolf, W. P. Menzel, W. J. Zhang, H. L. Huang and T. H. Achtor, "Global soundings of the atmosphere from ATOVS measurements: The algorithm and validation," J. Appl. Meteor., vol. 39, 1248-1268, 2000. 
[16] X. L. Ma, T. J. Schmit, and W. L. Smith, "A non-linear physical retrieval algorithm-its application to the GOES-8/9 sounder," J. Appl. Meteor., vol. 38, 501-513, 1999.

[17] J. V. Martins, D. Tanré, L. A. Remer, Y. J. Kaufman, S. Mattoo and R. Levy, “MODIS cloud screening for remote sensing of aerosol over oceans using spatial variability," Geophys. Res. Lett., vol. 29, no.12, DOI 10.1029/ 2001GL013205, 2002.

[18] W. P. Menzel and J. F. W. Purdom, "Introducing GOES-I: The 1st of a newgeneration of geostationary operational environmental satellites," Bull. Amer. Meteor. Soc., vol. 75, 757-781, 1994.

[19] W. P. Menzel, F. C. Holt, T. J. Schmit, R. M. Aune, A. J. Schreiner, G. S. Wade, and D. G. Gray, "Application of the GOES-8/9 soundings to weather forecasting and nowcasting," Bull. Amer. Meteor. Soc., vol. 79, 2059-2077, 1998.

[20] C. L. Parkinson and R. Greenstone, "EOS data products handbook. Volume 2," NASA NP-2000-5-055-GSFC, 253 pp., 2000 (available from eospso.gsfc.nasa.gov).

[21] S. Platnick, M. D. King, S. A. Ackerman, W. P. Menzel, B. A. Baum, J. C. Riédi, and R. A. Frey, "The MODIS cloud products: Algorithms and examples from Terra," IEEE Trans. Geosci. Remote Sens., this issue, 2002.

[22] L. A. Remer, Y. J. Kaufman, and B. N. Holben, "Interannual variation of ambient aerosol characteristics on the east coast of the United States," J. Geophys. Res., vol. 104, 2223-2232, 1999.

[23] L. A. Remer, D. Tanré, Y. J. Kaufman, C. Ichoku, S. Mattoo, R. Levy, D. A. Chu, B. N. Holben, O. Dubovik, A. Smirnov, J. V. Martins, R. R. Li and Z. Ahmad, "Validation of MODIS aerosol retrieval over ocean," Geophys. Res. 
Lett., vol. 29, no.12, DOI 10.1029/2001GL013204, 2002.

[24] L. S. Rothman, C. P. Rinsland, A. Goldman, S. T. Messie, D. P. Edwards, J. M. Flaud, A. Perri, C. Camy-Peyret, V. Dana, J. Y. Mandin, J. Schroeder, A. McCann, R. R. Gamach, R. B. Wattson, K. Yoshino, K. V. Chance, K. W. Jucks, L. R. Brown, V. Nemtchinov, and P. Varanasi, "The HITRAN molecular spectroscopic database and HAWKS (HITRAN Atmospheric Workstation): 1996 edition," J. Quant. Spectrosc. Radiat. Transfer, vol. 60, pp. 665-710, 1998.

[25] D. Tanré, Y. J. Kaufman, M. Herman, and S. Mattoo, "Remote sensing of aerosol properties over oceans using the MODIS/EOS spectral radiances," J. Geophys. Res., vol. 102, pp. 16971-16988, 1997. 
Michael D. King received the B.A. degree in physics from Colorado College in 1971, and the M.S. and Ph.D. degrees in atmospheric sciences from the University of Arizona in 1973 and 1977, respectively.

He joined NASA Goddard Space Flight Center in January 1978 and is currently Senior Project Scientist of NASA's Earth Observing System (EOS), a position he has held since 1992. He is a member of the MODIS Science Team where he has primary responsibility for developing the cloud optical and microphysical property and Level-3 algorithms. His research experience includes conceiving, developing, and operating multispectral scanning radiometers from a number of aircraft platforms in field experiments ranging from arctic stratus clouds to smoke from the Kuwait oil fires in the Persian Gulf and biomass burning in Brazil and southern Africa.

W. Paul Menzel received the B.S. degree in physics from the University of Maryland in 1967, and the M.S. and Ph.D. degrees in theoretical solid state physics from the University of Wisconsin in 1968 and 1974, respectively.

In 1975 he joined the Space Science and Engineering Center at the University of Wisconsin, where he was among the first to explore the possibilities for multispectral remote sensing of the Earth's atmosphere from a geosynchronous satellite. In 1983 he joined NOAA/NESDIS to head the Advanced Satellite Products Team that developed, tested and evaluated procedures for deriving new atmospheric products from spaceborne observations and transferred those from the research laboratory to the operational weather forecaster. Dr. Menzel is currently Chief Scientist in the Office of Research and Applications of NOAA/NESDIS. He is a member of the MODIS Science Team working on algorithms to derive cloud top properties, atmospheric profiles, and column water vapor using infrared bands on MODIS. 
Yoram J. Kaufman received the B.Sc. and M.Sc. degrees in physics from the Technion-Israel Institute of Technology, Israel, in 1972 and 1974, respectively, and the Ph.D. degree from Tel-Aviv University in 1979. He came to NASA Goddard Space Flight Center in 1979 as an NRC Resident Research Associate. He is currently an atmospheric scientist in the Laboratory for Atmospheres at NASA Goddard Space Flight Center.

His present research includes theoretical and experimental investigations in atmospheric science, radiative transfer, and remote sensing. His research experience includes remote sensing of aerosols and clouds, atmospheric correction of satellite imagery of the earth's surface, interaction of aerosols with clouds and their subsequent impact on climate, remote sensing of emissions from biomass burning in the topics, and calibration of satellite sensors. He is a member of the MODIS Science Team where he has primary responsibility for the remote sensing of tropospheric aerosol properties over land surfaces and served as Project Scientist of Terra from 1996-2000.

Didier Tanré received the M.Sc. degree in physics in 1975 and the "Thèse de 3 ème Cycle" and "Doctorat d'Etat" in atmospheric physics in 1977 and 1982, respectively, all from the Université des Sciences et Techniques de Lille, France.

$\mathrm{He}$ is an atmospheric scientist in the CNRS (Centre National de la Recherche Scientifique), collocated with the Laboratoire d'Optique Atmospherique at the Université des Sciences et Technologies de Lille, France, where he has been a research scientist since 1982. He is a member of the MODIS Science Team, where he has primary responsibility for remote sensing of tropospheric aerosol over the ocean. He is currently the Director of the Laboratoire d'Optique Atmosphérique at the Université des Sciences et Technologies de Lille. 
Bo-Cai Gao received the B.S. degree in physics from Nankai University in the People's Republic of China in 1982, and the M.S. and Ph.D. degrees in physics from the Ohio State University in 1984 and 1988, respectively.

He is presently with the Remote Sensing Division, Naval Research Laboratory, Washington, DC. He is a member of the MODIS Science Team, where his focus is on the remote sensing of cirrus clouds, atmospheric water vapor, and coastal water. He received a Prize Paper Award from the IEEE Geoscience and Remote Sensing Society in 1991 for his development of an operational atmospheric radiative transfer code to retrieve surface reflectance spectra from hyperspectral imaging data measured with the NASA/JPL Airborne Visible/Infrared Imaging Spectrometer (AVIRIS).

Steven Platnick received the B.S. degree in electrical engineering from Duke University in 1979, the M.S. degree in electrical engineering from the University of California Berkeley in 1980, and the Ph.D. degree in atmospheric sciences from the University of Arizona in 1991.

$\mathrm{He}$ is a Research Associate Professor in the Joint Center for Earth Systems Technology, University of Maryland Baltimore County, a position he has held since 1996. He has worked in collaboration with NASA Goddard Space Flight Center since 1993, and prior to that held engineering positions at HewlettPackard Co. for 6 years as well as a National Research Council Resident Research Associate position at NASA Ames Research Center. His research experience includes theoretical and experimental studies of satellite, aircraft, and groundbased cloud remote sensing, including applications to MODIS. He is an associate member of the MODIS Science Team.

Steven A. Ackerman received the Ph.D. degree in atmospheric sciences from 
Colorado State University in 1987.

He is a Professor in the Department of Atmospheric and Oceanic Sciences, University of Wisconsin, Madison, where he first joined the faculty in 1992. He is also the Director of the Cooperative Institute for Meteorological Satellite Studies (CIMSS), a position he has held since 1999. He is an associate member of the MODIS Science Team where he has primary responsibility for the MODIS cloud mask algorithm. His research experience includes remote sensing, radiative transfer, Earth radiation budgets, cloud radiative parameterizations, climate change; and aerosol studies. In addition to his participation in the MODIS Science Team, he is responsible for the cloud mask algorithm on the Global Imager (GLI), a sensor on Japan's ADEOS II spacecraft.

Lorraine A. Remer received the B.S. and Ph.D. degrees in atmospheric science from the University of California, Davis in 1980 and 1991, and the M.S. in oceanography from the Scripps Institution of Oceanography, University of California, San Diego in 1983.

She became involved with the MODIS retrievals of atmospheric aerosols in 1991, first as a research scientist with Science Systems and Applications, Inc., and subsequently with NASA, which she joined in 1998. She is an associate member of the MODIS Science Team and a member of the Global Aerosol Climatology Project Science Team. Her current research interests are the climatic effects and remote sensing of atmospheric aerosol. She has been involved in several field campaigns including the Smoke/Sulfate, Clouds, and Radiation (SCAR) experiments, the Tropospheric Aerosol Radiative Forcing Observational Experiment (TARFOX), the Israeli Desert Transition Zone Experiment, and the Puerto Rico Dust Experiment (PRiDE). 
Robert Pincus received the Ph.D. degree in atmospheric sciences from the University of Washington in 1994. He came to NASA Goddard Space Flight Center in 1994 as an NRC Resident Research Associate, where he worked until joining the University of Wisconsin as a visiting professor in 1998. He is currently a research scientist in the NOAA-CIRES Climate Diagnostics Center.

His research experience includes clouds as they relate to the earth's radiation budget and climate, including descriptions and simple models of horizontal and vertical structure, methods of remote sensing, and the representation of clouds in climate models. He designed the fundamental architecture behind the MODIS Level-3 joint atmosphere tile and daily products.

Paul A. Hubanks received the B.S. degree in mathematics from the University of Georgia in 1979 and completed two years in the M.S. meteorology program at Penn State University from 1979 to 1981.

He has more than 20 years' experience in satellite and aircraft data analysis and evaluation, solar and terrestrial research, scientific algorithm development and verification, software design-development-maintenance, data visualization, data analysis, and data management. In addition, he is an expert in designing and engineering state of the art world wide web sites and optimizing graphics and image data for the web, including the MODIS Atmosphere web site. 
Table I

MODIS ATMOSPHERE DATA PRODUCTS, RESPONSIBLE INVESTIGATOR, PROCESSING LEVEL, Product ID, SPATIAL RESOlution, FILE FrEQUENCY, AND File SizE.

\begin{tabular}{|c|c|c|c|c|c|c|}
\hline Data Set & $\begin{array}{l}\text { Responsible } \\
\text { Investigators }\end{array}$ & $\begin{array}{l}\text { Process- } \\
\text { ing Level }\end{array}$ & $\begin{array}{l}\text { Product } \\
\text { ID }^{\mathrm{a}}\end{array}$ & $\begin{array}{c}\text { Spatial } \\
\text { Resolution } \\
(\mathrm{km}) \\
\end{array}$ & $\begin{array}{l}\text { File } \\
\text { Frequency }\end{array}$ & File Size \\
\hline \multicolumn{7}{|l|}{ Pixel-level products } \\
\hline Cloud mask & $\begin{array}{c}\text { Ackerman, } \\
\text { Menzel }\end{array}$ & 2 & MOD35 & $0.25,1$ & $288 /$ day & $47.4 \mathrm{MB}$ \\
\hline Aerosol product & $\begin{array}{l}\text { Kaufman, } \\
\text { Tanré, Remer }\end{array}$ & 2 & MOD04 & 10 & $139 /$ day & $12.0 \mathrm{MB}$ \\
\hline Total precipitable water & $\begin{array}{l}\text { Gao, Kaufman, } \\
\text { Tanré, Menzel }\end{array}$ & 2 & MOD05 & $\begin{array}{l}1 \text { (NIR), } \\
5 \text { (TIR) }\end{array}$ & $288 /$ day & $\begin{array}{l}20.2 \mathrm{MB} \text { (day) } \\
3.6 \mathrm{MB} \text { (night) }\end{array}$ \\
\hline Cloud product & $\begin{array}{l}\text { King, Platnick, } \\
\text { Menzel, Gao }\end{array}$ & 2 & MOD06 & $1,5^{\mathrm{b}}$ & $288 /$ day & $\begin{array}{c}\text { 69.6 MB (day) } \\
14.1 \mathrm{MB} \text { (night) }\end{array}$ \\
\hline Atmospheric profiles & Menzel & 2 & MOD07 & 5 & $288 /$ day & $32.2 \mathrm{MB}$ \\
\hline \multicolumn{7}{|l|}{ Gridded time-averaged products } \\
\hline $\begin{array}{l}\text { Level-3 atmosphere prod- } \\
\text { ucts }\end{array}$ & $\begin{array}{l}\text { King, Hubanks, } \\
\text { Pincus }\end{array}$ & 3 & MOD08 & $1^{\circ} \times 1^{\circ}$ & $\begin{array}{l}\text { 1/day } \\
1 / 8 \text {-day } \\
1 / \text { month }\end{array}$ & $\begin{array}{l}440.9 \mathrm{MB} \\
810.6 \mathrm{MB} \\
810.6 \mathrm{MB}\end{array}$ \\
\hline
\end{tabular}

aODxx products apply to Terra and MYDxx products apply to Aqua.

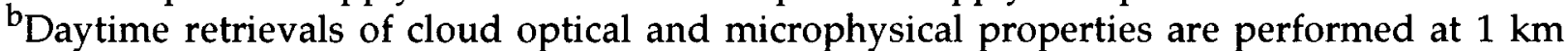
resolution, while daytime and nighttime cloud top altitude and cloud top pressure are processed at $5 \mathrm{~km}[21]$. 
Table II

MODIS CLOUD PARAMETERS THAT APPEAR IN JOINT HISTOGRAMS.

\begin{tabular}{|c|c|c|c|c|}
\hline Parameter 1 & $\begin{array}{l}\text { Day/ } \\
\text { Night }\end{array}$ & Bin Boundaries & Parameter 2 & Bin Boundaries \\
\hline \multicolumn{5}{|l|}{ Liquid water clouds } \\
\hline Optical thickness & Day & $\begin{array}{r}0,2,4,6,8,10,15 \\
20,30,40,50,100\end{array}$ & Effective radius $(\mu \mathrm{m})$ & $\begin{array}{c}2,4,6,8,10,12.5,15,17.5 \\
20,25,30\end{array}$ \\
\hline Optical thickness & Day & $\begin{array}{c}0,2,4,6,8,10,15 \\
20,30,40,50,100\end{array}$ & $\begin{array}{l}\text { Cloud top tempera- } \\
\text { ture }(\mathrm{K})\end{array}$ & $\begin{array}{c}230,235,240,245,250,255, \\
260,265,270,275,280,285, \\
290\end{array}$ \\
\hline Optical thickness & Day & $\begin{array}{c}0,2,4,6,8,10,15 \\
20,30,40,50,100\end{array}$ & Effective emissivity & $\begin{array}{c}0.0,0.1,0.2,0.3,0.4,0.5 \\
0.7,0.8,0.9,1.0\end{array}$ \\
\hline Effective radius $(\mu \mathrm{m})$ & Day & $\begin{array}{c}2,4,6,8,10,12.5,15 \\
17.5,20,25,30\end{array}$ & $\begin{array}{l}\text { Cloud top tempera- } \\
\text { ture }(\mathrm{K})\end{array}$ & $\begin{array}{c}230,235,240,245,250,255, \\
260,265,270,275,280,285, \\
290\end{array}$ \\
\hline Effective radius $(\mu \mathrm{m})$ & Day & $\begin{array}{c}2,4,6,8,10,12.5,15 \\
17.5,20,25,30\end{array}$ & Effective emissivity & $\begin{array}{c}0.0,0.1,0.2,0.3,0.4,0.5 \\
0.7,0.8,0.9,1.0\end{array}$ \\
\hline \multicolumn{5}{|l|}{ Ice clouds } \\
\hline Optical thickness & Day & $\begin{array}{c}0,0.5,1,2.5,5,7.5 \\
10,15,20,30,50,100\end{array}$ & Effective radius $(\mu \mathrm{m})$ & $\begin{array}{c}6,8,10,15,20,25,30,35 \\
40,45,50,55,60\end{array}$ \\
\hline Optical thickness & Day & $\begin{array}{c}0,0.5,1,2.5,5,7.5 \\
10,15,20,30,50,100\end{array}$ & $\begin{array}{l}\text { Cloud top tempera- } \\
\text { ture }(\mathrm{K})\end{array}$ & $\begin{array}{c}220,225,230,235,240,245 \\
250,255,260,265,270\end{array}$ \\
\hline Optical thickness & Day & $\begin{array}{c}0,0.5,1,2.5,5,7.5 \\
10,15,20,30,50,100\end{array}$ & Effective emissivity & $\begin{array}{c}0.0,0.1,0.2,0.3,0.4,0.5 \\
0.7,0.8,0.9,1.0\end{array}$ \\
\hline Effective radius $(\mu \mathrm{m})$ & Day & $\begin{array}{c}2,4,6,8,10,12.5,15 \\
17.5,20,25,30\end{array}$ & $\begin{array}{l}\text { Cloud top tempera- } \\
\text { ture }(\mathrm{K})\end{array}$ & $\begin{array}{c}220,225,230,235,240,245 \\
250,255,260,265,270\end{array}$ \\
\hline Effective radius $(\mu \mathrm{m})$ & Day & $\begin{array}{c}2,4,6,8,10,12.5,15 \\
17.5,20,25,30\end{array}$ & Effective emissivity & $\begin{array}{c}0.0,0.1,0.2,0.3,0.4,0.5 \\
0.7,0.8,0.9,1.0\end{array}$ \\
\hline \multicolumn{5}{|l|}{ All clouds } \\
\hline $\begin{array}{l}\text { Cloud top pressure } \\
(\mathrm{hPa})\end{array}$ & Day & $1,400,700,1000$ & Effective emissivity & $0.0,0.5,0.95,1.0$ \\
\hline $\begin{array}{l}\text { Cloud top pressure } \\
(\mathrm{hPa})\end{array}$ & Night & $1,400,700,1000$ & Effective emissivity & $0.0,0.5,0.95,1.0$ \\
\hline $\begin{array}{l}\text { Cloud top pressure } \\
(\mathrm{hPa})\end{array}$ & $\begin{array}{l}\text { Day }+ \\
\text { Night }\end{array}$ & $1,400,700,1000$ & Effective emissivity & $0.0,0.5,0.95,1.0$ \\
\hline
\end{tabular}




\section{FIGURE LEGENDS}

Fig. 1. MODIS atmosphere data processing architecture and products (adapted from [20]).

Fig. 2. Cloud mask over Western Australia on June 5, 2001. Panel (a) is a true color composite of one MODIS granule using bands at $0.645,0.555$, and $0.469 \mu \mathrm{m}$. Panel (b) is the cloud mask derived for this scene, showing the various confidence levels of cloud identified in this scene.

Fig. 3. Atmospheric temperatures retrieved from Terra-MODIS radiances on May 22, 2001 at (a) $850 \mathrm{hPa}$, (b) $700 \mathrm{hPa}$, and (c) $500 \mathrm{hPa}$.

Fig. 4. Cross-section of (a) temperature and (b) mixing ratio along a cross section in the southeastern United States (white line in panel (c)), which shows the thermal infrared-derived total precipitable water vapor for an Aqua-MODIS granule on September 4. 2002. (d) The associated GOES-8 Sounder depiction of the total precipitable water vapor. The white bars in (a) and (b) correspond to regions obscured by cloud.

Fig. 5. Comparison of total precipitable water from MODIS thermal-infrared regression (solid circles), GOES-8 (open circles), and radiosonde (open diamonds) with the SGP ARM-CART microwave radiometer (MWR) in millimeters. 80 MODIS cases from April 1 to September 1, 2002 are shown in the comparison.

Fig. 6. Aerosol optical thickness over the Eastern United States on May 4, 2001. Panel (a) is a true color composite of one MODIS granule, showing cloud cover over northern New York, central Florida, and the nearby Atlantic Ocean. Panels (b) and (d) show the aerosol optical thickness at $0.56 \mu \mathrm{m}$ and the effective radius derived for this scene, showing pollution along the Ohio Valley and transport to the north Atlantic. Panel (c) shows the ratio of aerosol optical thickness of the fine to the total aerosol optical 
thickness. Gray areas denote areas where no retrieval is possible due to sunglint, bright land, and clouds.

Fig. 7. Water vapor over the eastern United States on June 24, 2002. Panel (a) is a false color composite of one Terra-MODIS granule using bands at $0.645,0.858$, and $0.469 \mu \mathrm{m}$, showing cloud cover over the upper Midwest and Mid-Atlantic regions of the United States. Panel (b) is total precipitable water derived from the cloud-free pixels over land using the nearinfrared algorithm. Panel (c) is the total precipitable water derived from the thermal infrared algorithm.

Fig. 8. Cloud properties over the western Pacific Ocean off the Kamchatka Peninsula on August 10, 2001. Panel (a) is a true color composite of one MODIS granule, showing marine stratocumulus clouds with ship tracks as well as upper level ice clouds. Panels (b) and (d) show the cloud optical thickness and effective radius derived from all cloudy pixels, where we have used a separate color bar to denote clouds processed as ice and water clouds. Panel (c) shows the cloud top pressure for all clouds in this scene.

Fig. 9. Level-3 monthly averages of (a) cloud optical thickness, (b) aerosol optical thickness, and (c) near-infrared precipitable water for August 2001. These monthly products are produced at a $1^{\circ} \times 1^{\circ}$ latitude-longitude grid worldwide.

Fig. 10. Histogram of the joint probability of cloud optical thickness and effective radius derived from the Level-3 joint atmosphere product for August 2001 for a region off the coast of Peru and Chile bounded by $12^{\circ}$ $24^{\circ} \mathrm{S}$ and $68^{\circ}-80^{\circ} \mathrm{W}$. All liquid water cloud retrievals over ocean in this latitude-longitude box have been aggregated. The grid pattern reflects 
the bin boundaries in this Level-3 data product. 


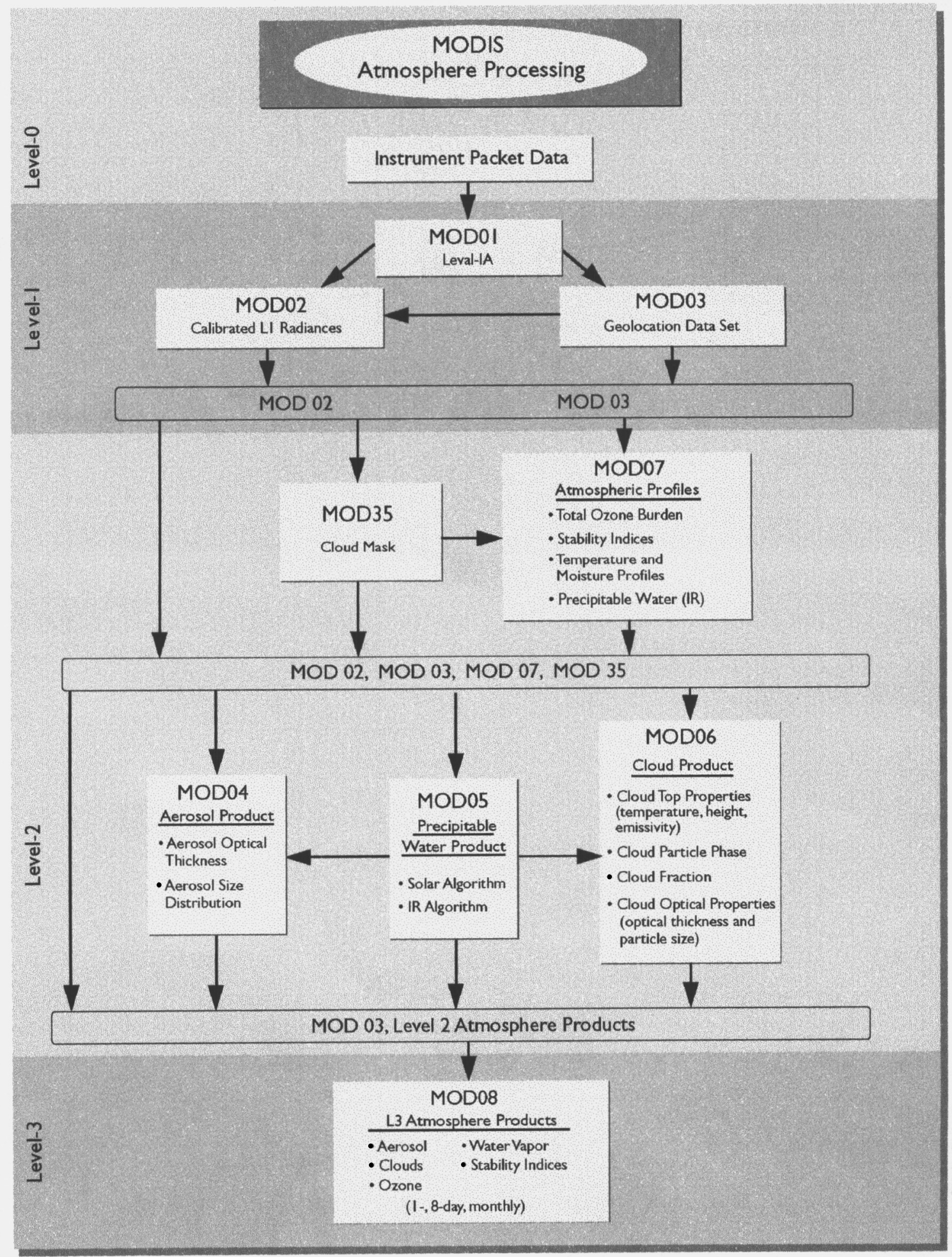

Fig. 1. MODIS atmosphere data processing architecture and products (adapted from [20]). 
a) $R(0.645,0.555,0.469)$

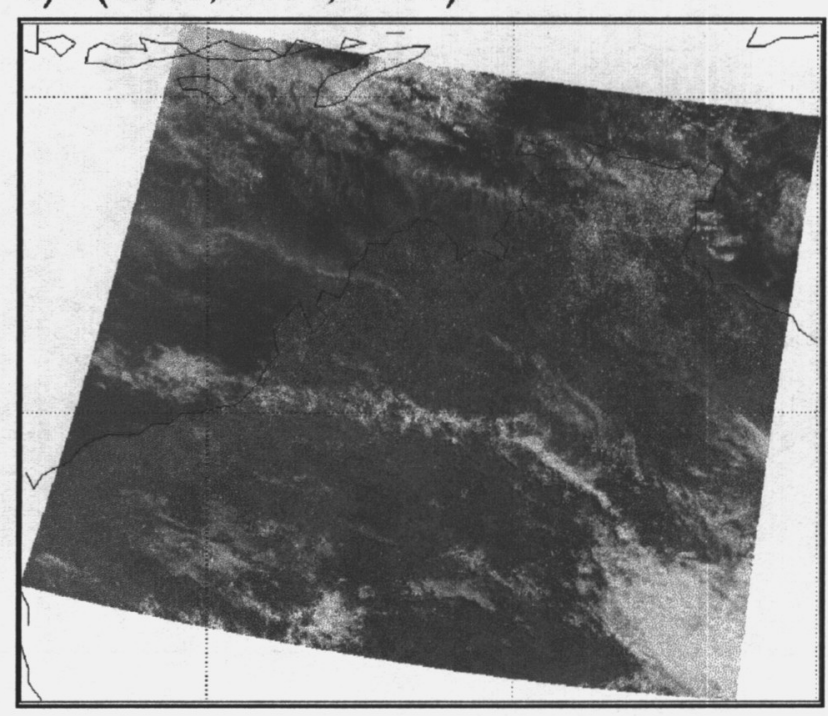

b) Cloud Mask

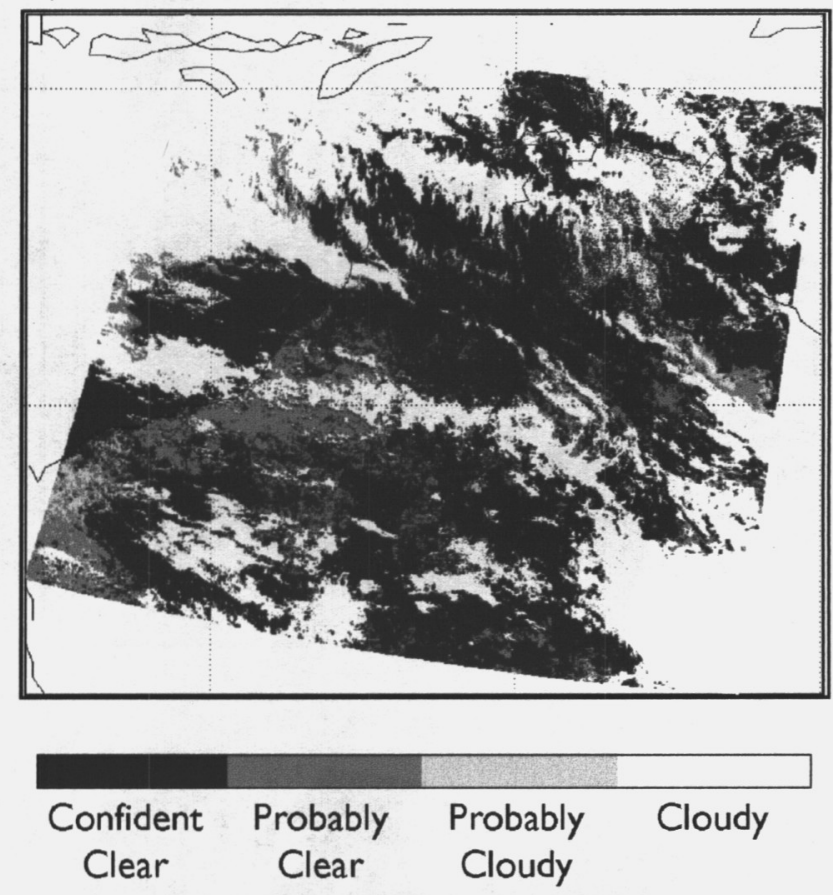

Fig. 2. Cloud mask over Western Australia on June 5, 2001. Panel (a) is a true color composite of one MODIS granule using bands at $0.645,0.555$, and $0.469 \mu \mathrm{m}$. Panel (b) is the cloud mask derived for this scene, showing the various confidence levels of cloud identified in this scene. 
a) $T(850 \mathrm{hPa})$

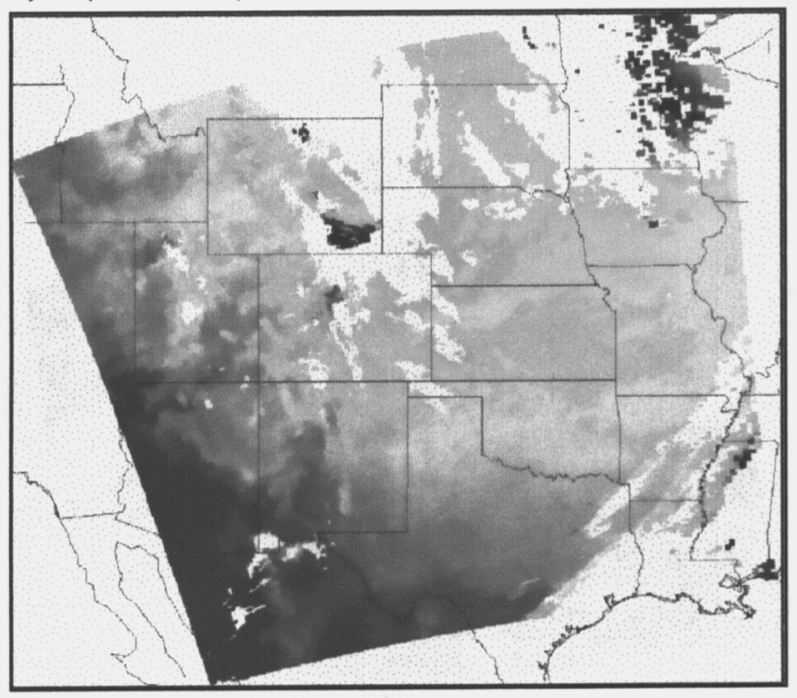

c) $T(500 \mathrm{hPa})$

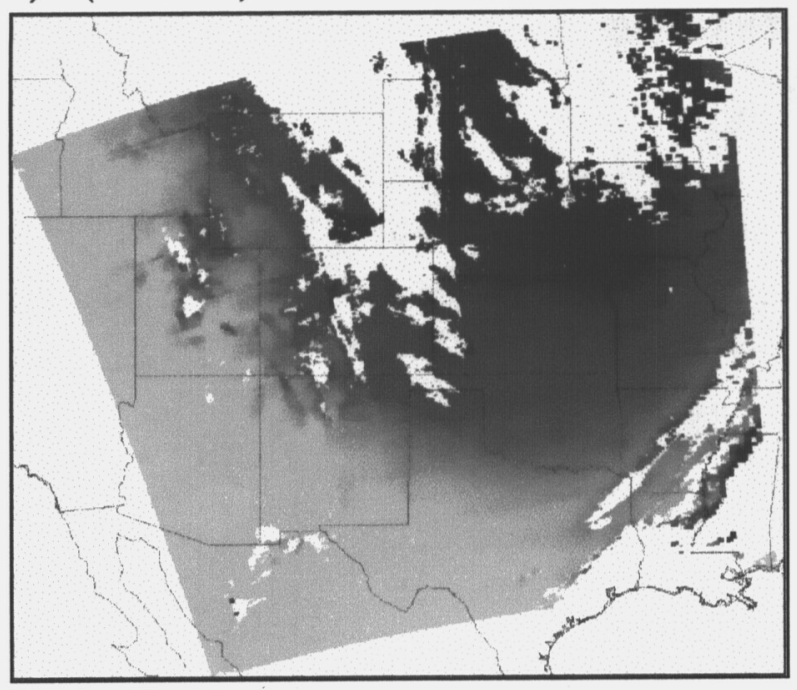

b) $T(700 \mathrm{hPa})$
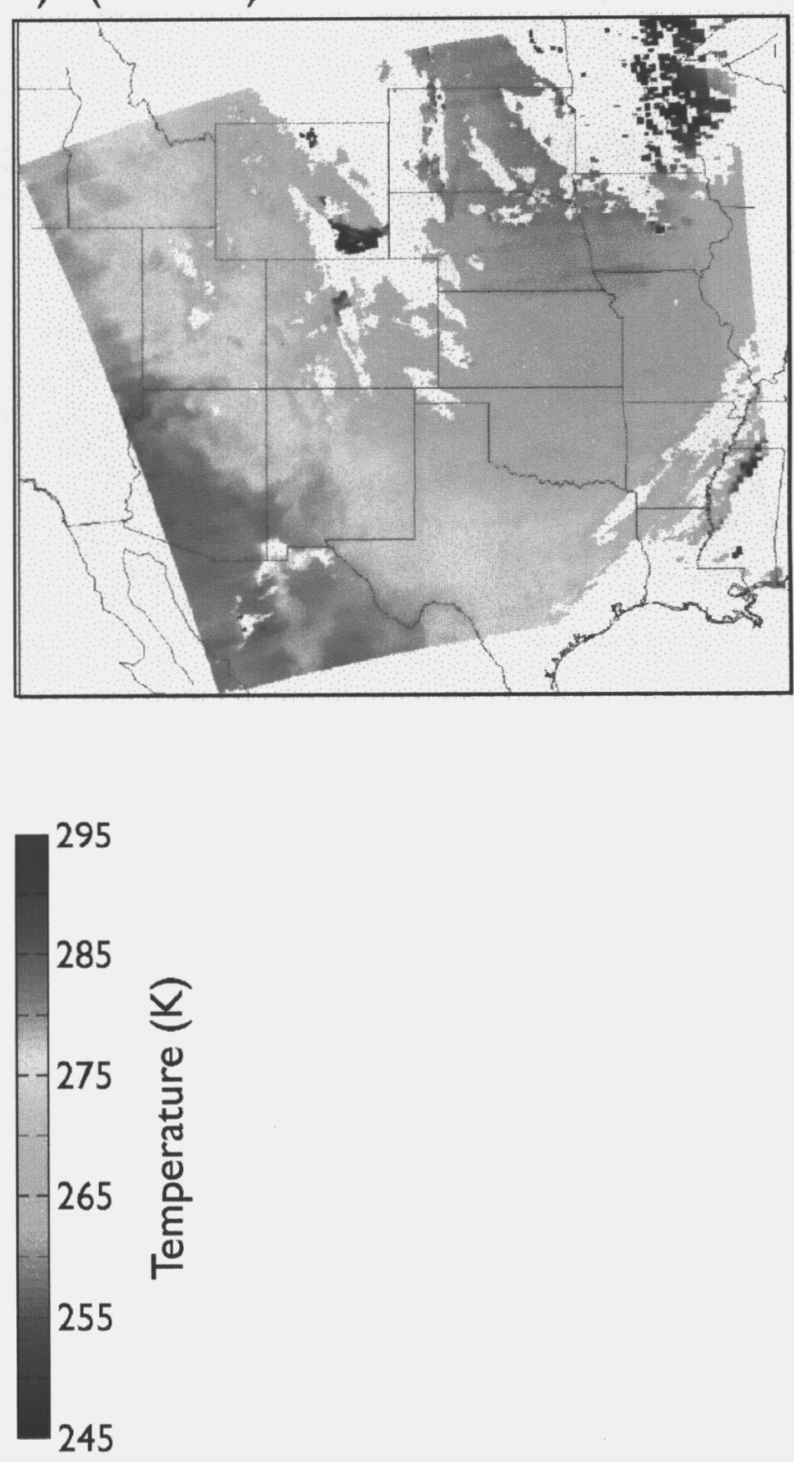

Fig. 3. Atmospheric temperatures retrieved from Terra-MODIS radiances on May 22, 2001 at (a) $850 \mathrm{hPa}$, (b) $700 \mathrm{hPa}$, and (c) $500 \mathrm{hPa}$. 

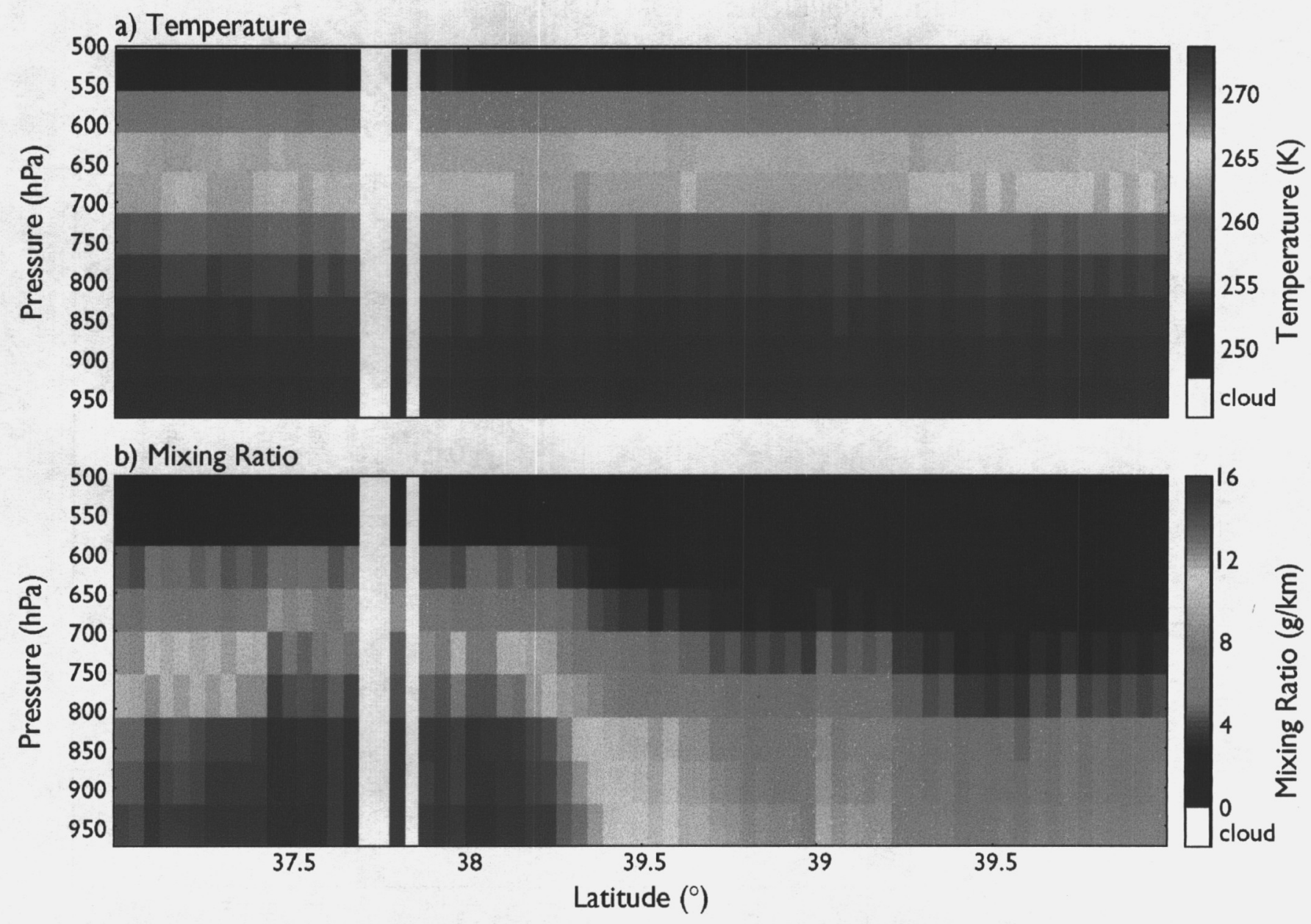

c) Aqua Precipitable Water

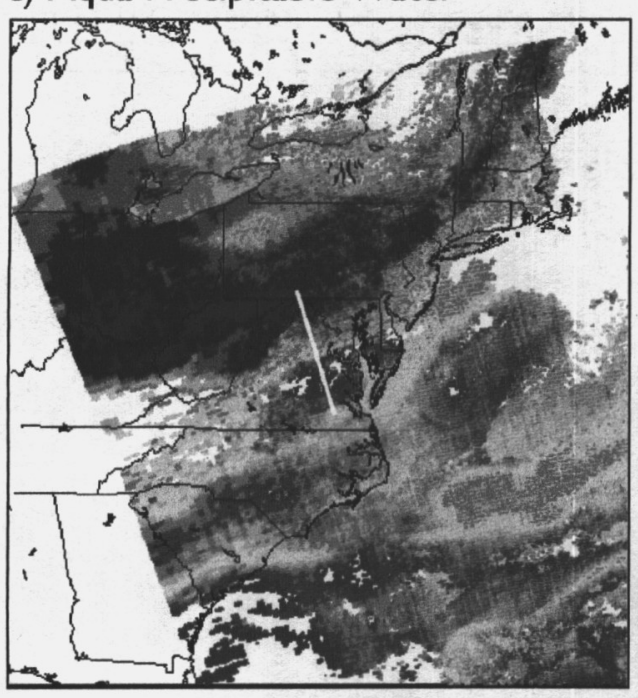

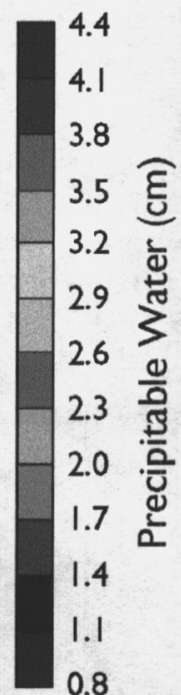

d) GOES-8 Sounder Precipitable Water

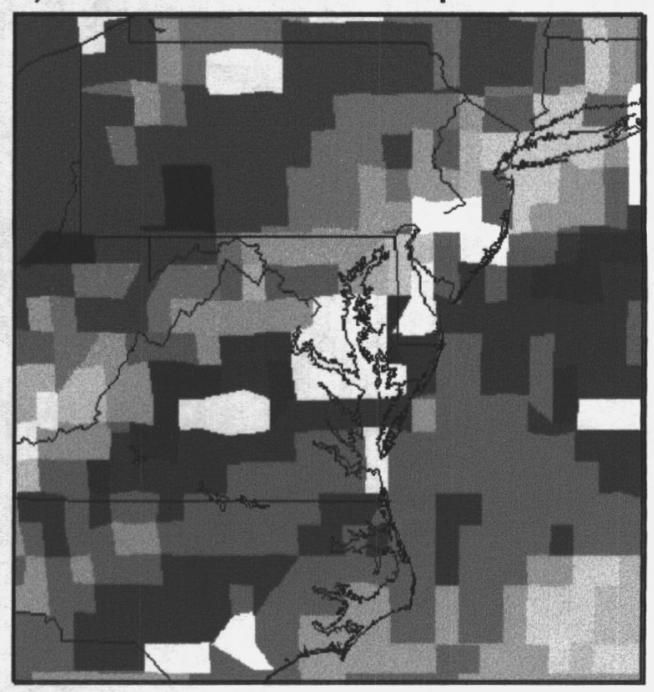

Fig. 4. Cross-section of (a) temperature and (b) mixing ratio along a cross section in the southeastern United States (white line in panel (c)), which shows the thermal infrared-derived total precipitable water vapor for an Aqua-MODIS granule on September 4. 2002. (d) The associated GOES-8 Sounder depiction of the total precipitable water vapor. The white bars in (a) and (b) correspond to regions obscured by cloud. 


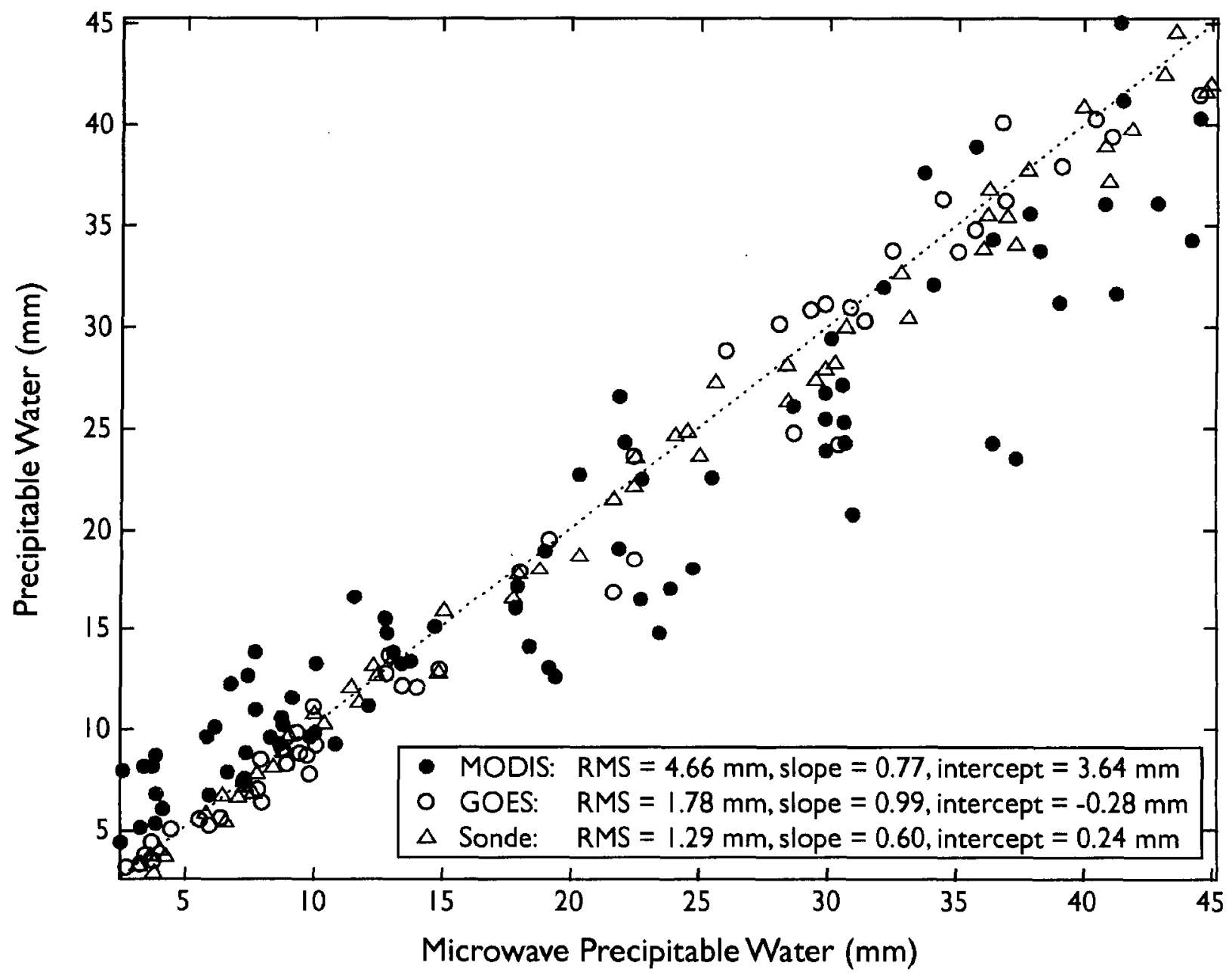

Fig. 5. Comparison of total precipitable water from MODIS regression (solid circles), GOES-8 (open circles), and radiosonde (open diamonds) with the SGP ARM-CART microwave radiometer (MWR) in millimeters. 80 MODIS cases from April 1 to September 1, 2002 are shown in the comparison. 
a) $R(0.645,0.555,0.469)$

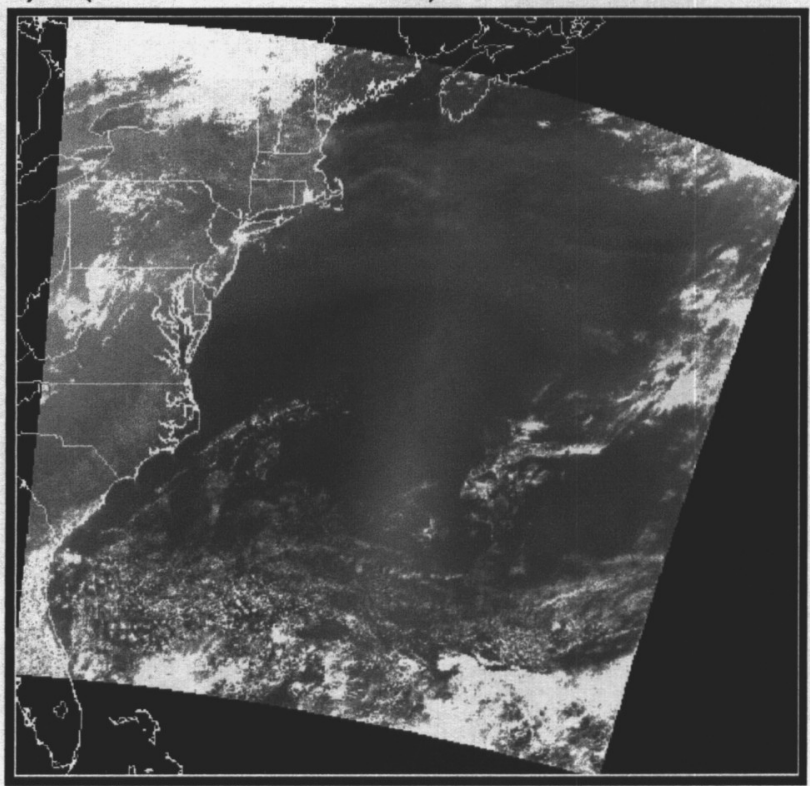

c) $\tau_{a}($ fine mode $) / \tau_{a}$ (total)

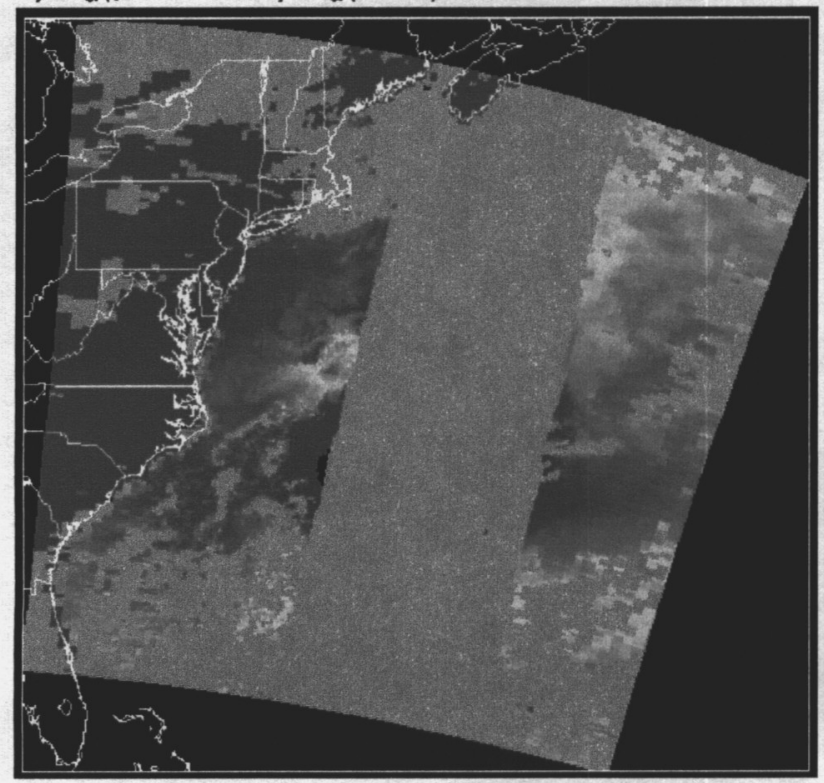

$\begin{array}{llllll}0.0 & 0.2 & 0.4 & 0.6 & 0.8 & 1.0\end{array}$ b) Aerosol Optical Thickness

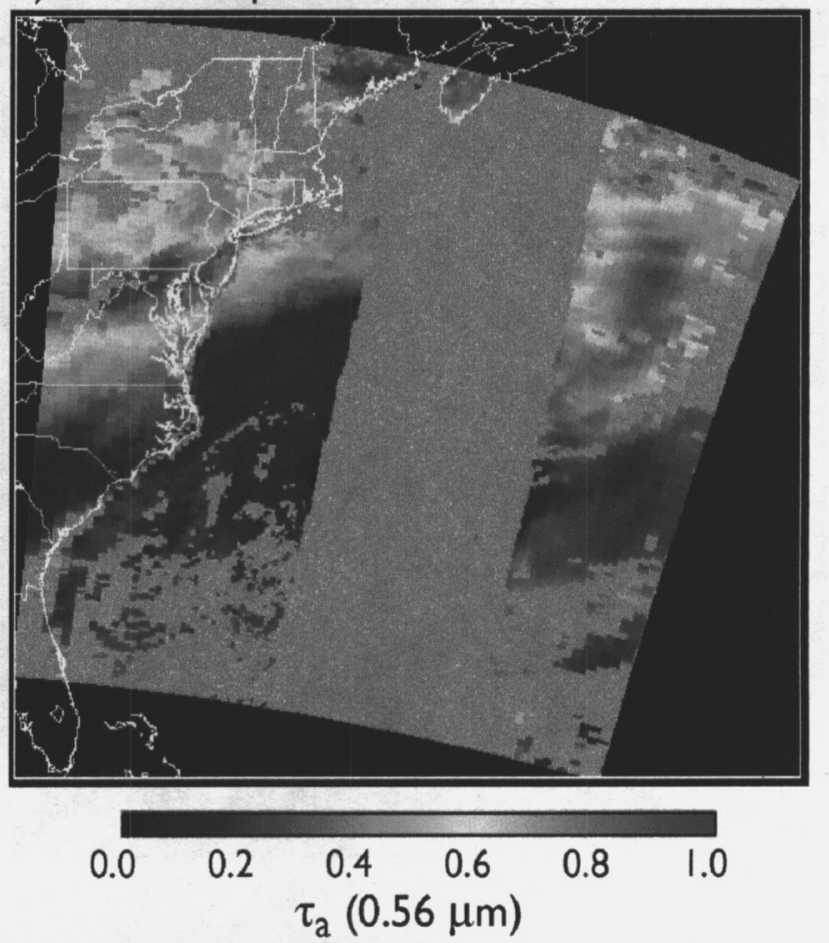

d) Effective Radius $(\mu \mathrm{m})$

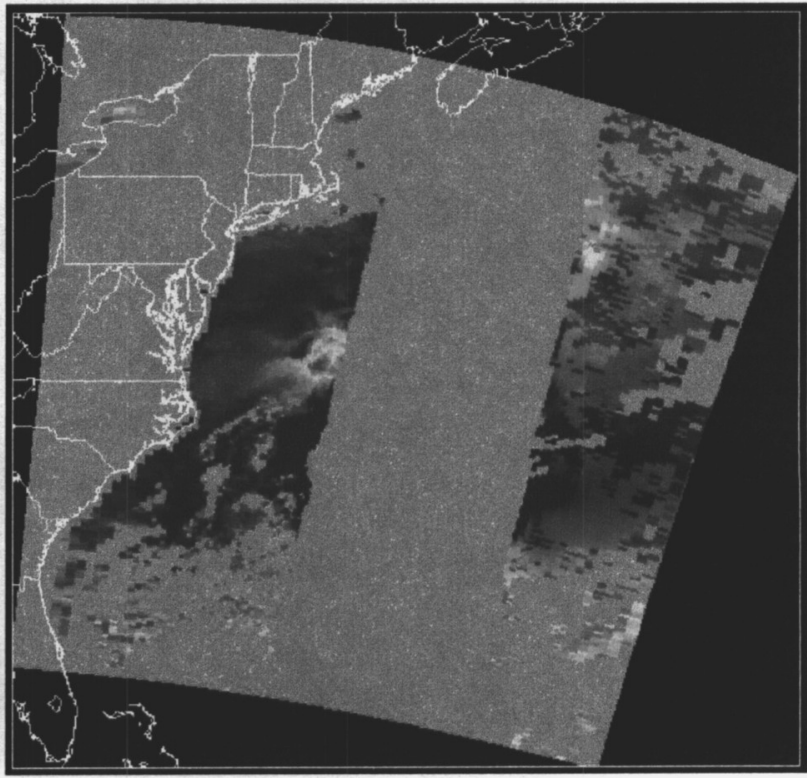

$\begin{array}{llllll}0.0 & 0.2 & 0.4 & 0.6 & 0.8 & 1.0\end{array}$

Fig. 6. Aerosol optical thickness over the Eastern United States on May 4, 2001. Panel (a) is a true color composite of one MODIS granule, showing cloud cover over northern New York, central Florida, and the nearby Atlantic Ocean. Panels (b) and (d) show the aerosol optical thickness at $0.56 \mu \mathrm{m}$ and the effective radius derived for this scene, showing pollution along the Ohio Valley and transport to the north Atlantic. Panel (c) shows the ratio of aerosol optical thickness between the fine and coarse particle mode. Gray areas denote areas where no retrieval is possible due to sunglint, bright land, and clouds. 
a) $R(0.645,0.858,0.469)$

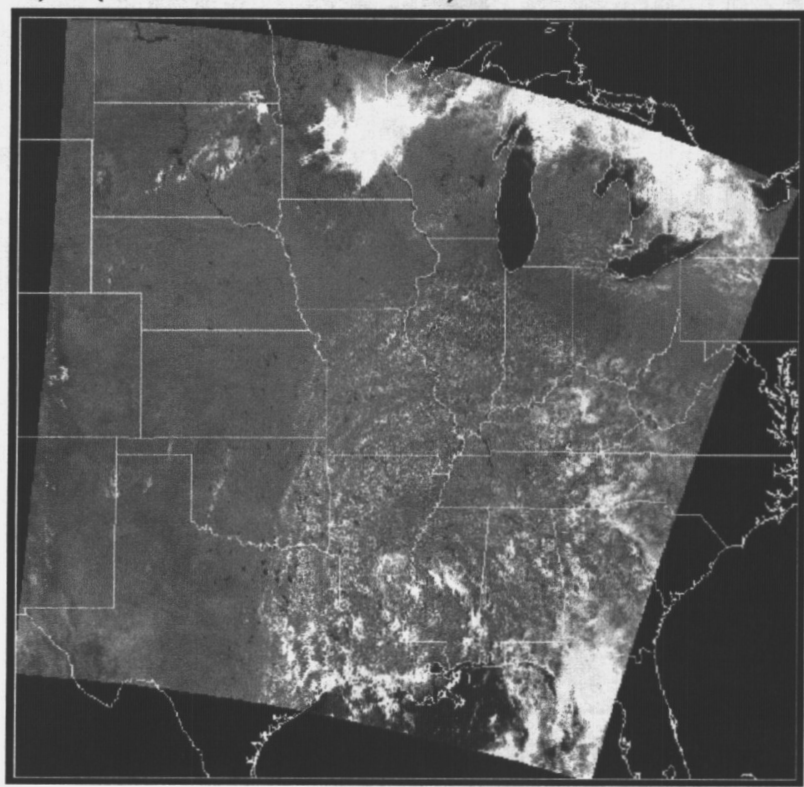

b) Near-Infrared Precipitable Water
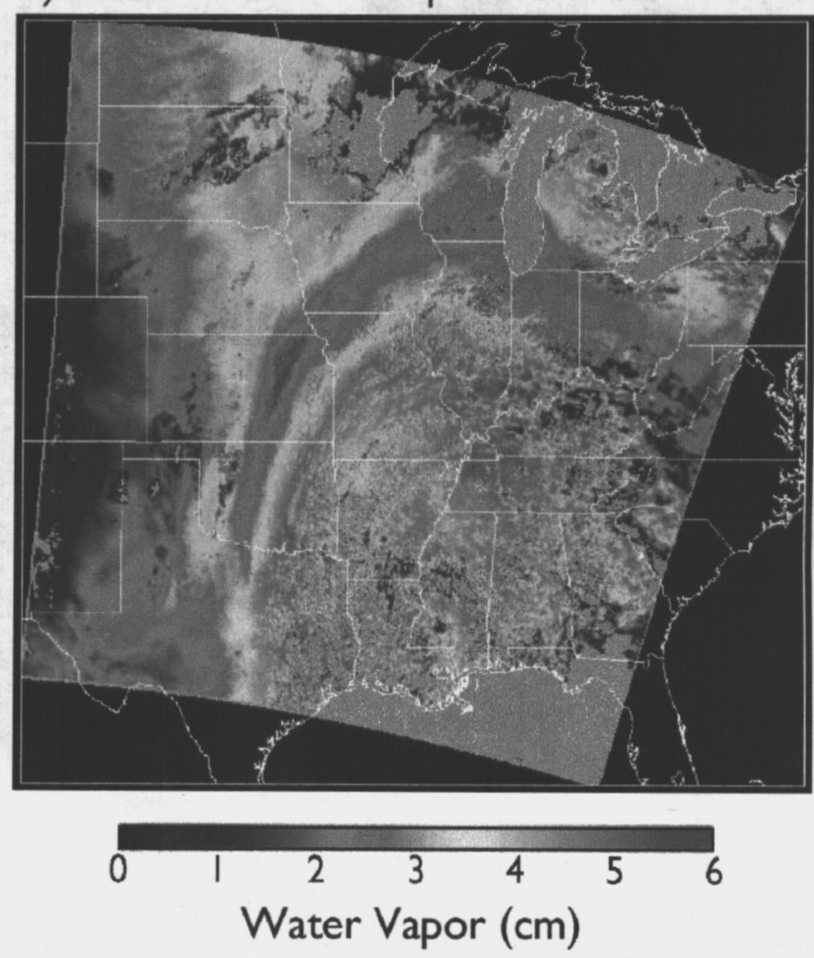

c) Thermal Infrared Precipitable Water

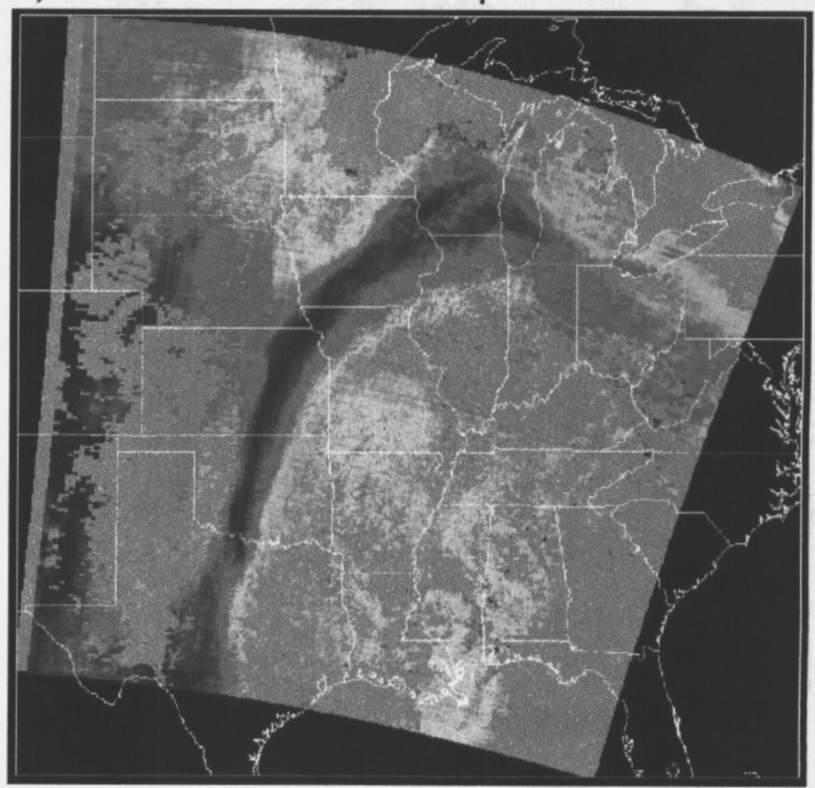

Fig. 7. Water vapor over the eastern United States on June 24, 2002. Panel (a) is a false color composite of one Terra-MODIS granule using bands at $0.645,0.858$, and $0.469 \mu \mathrm{m}$, showing cloud cover over the upper Midwest and Mid-Atlantic regions of the United States. Panel (b) is total precipitable water derived from the cloud-free pixels over land using the nearinfrared algorithm. Panel (c) is the total precipitable water derived from the thermal infrared algorithm. 
a) $R(0.645,0.555,0.469)$

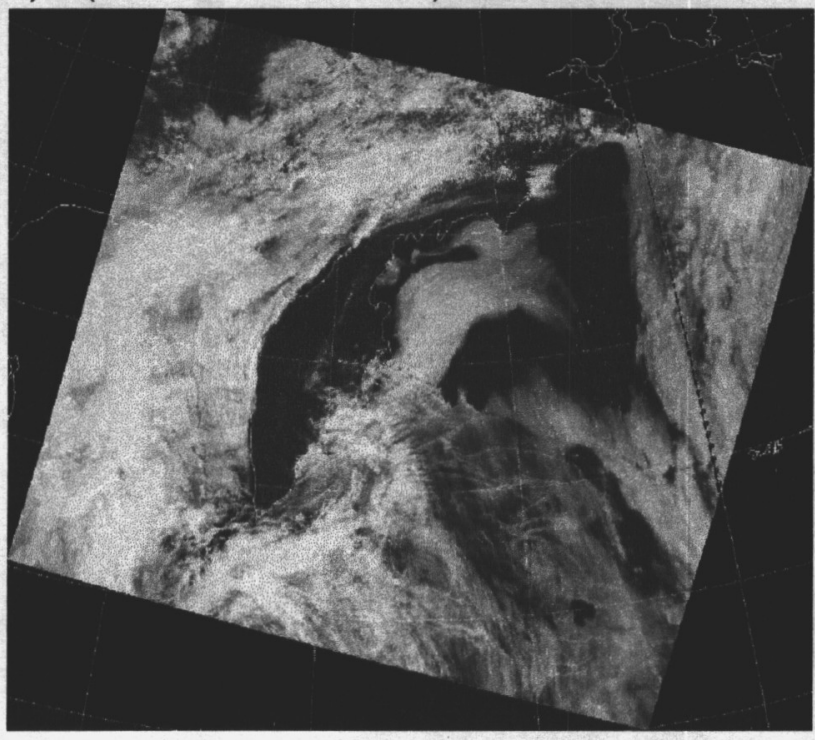

c) Cloud Top Pressure (hPa)

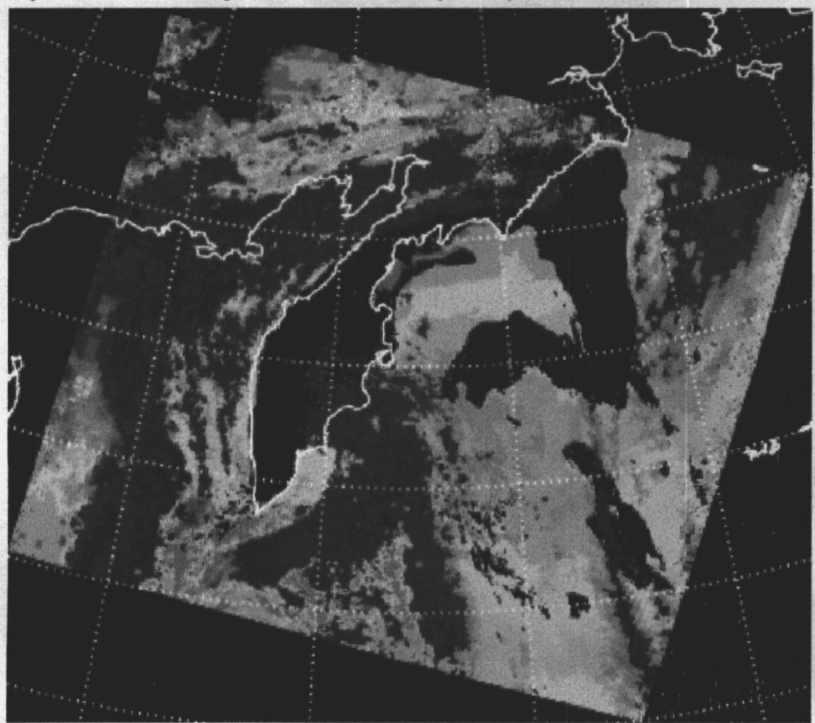

300

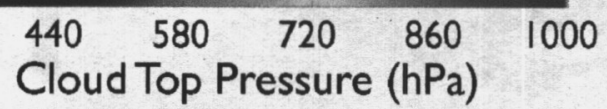

b) Cloud Optical Thickness

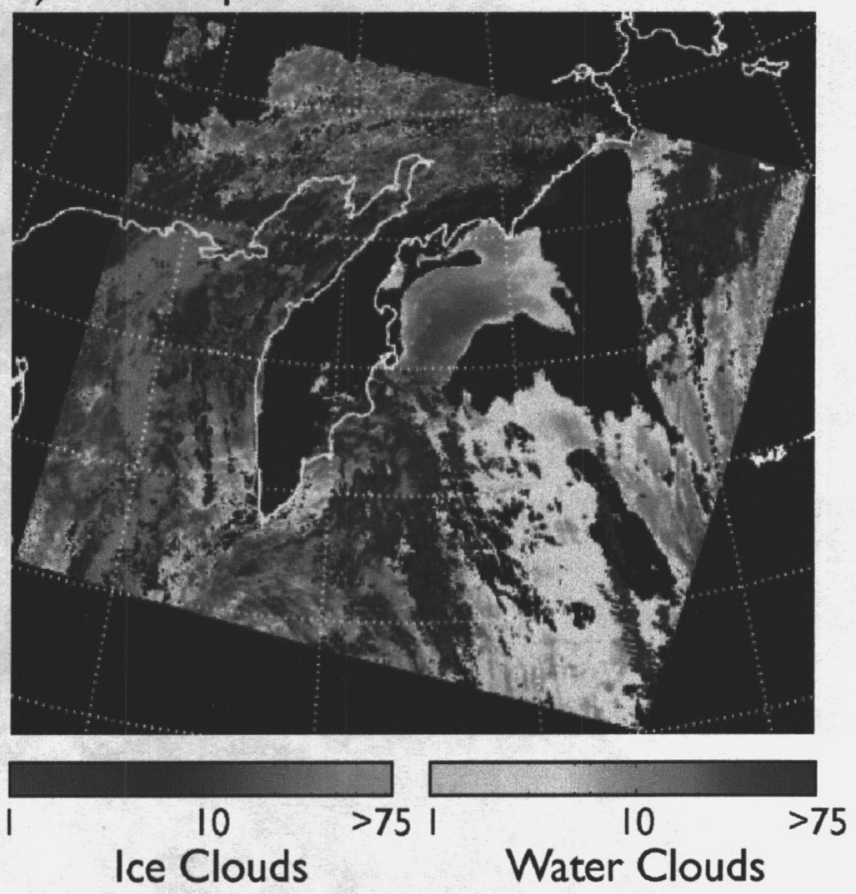

d) Cloud Effective Radius $(\mu \mathrm{m})$

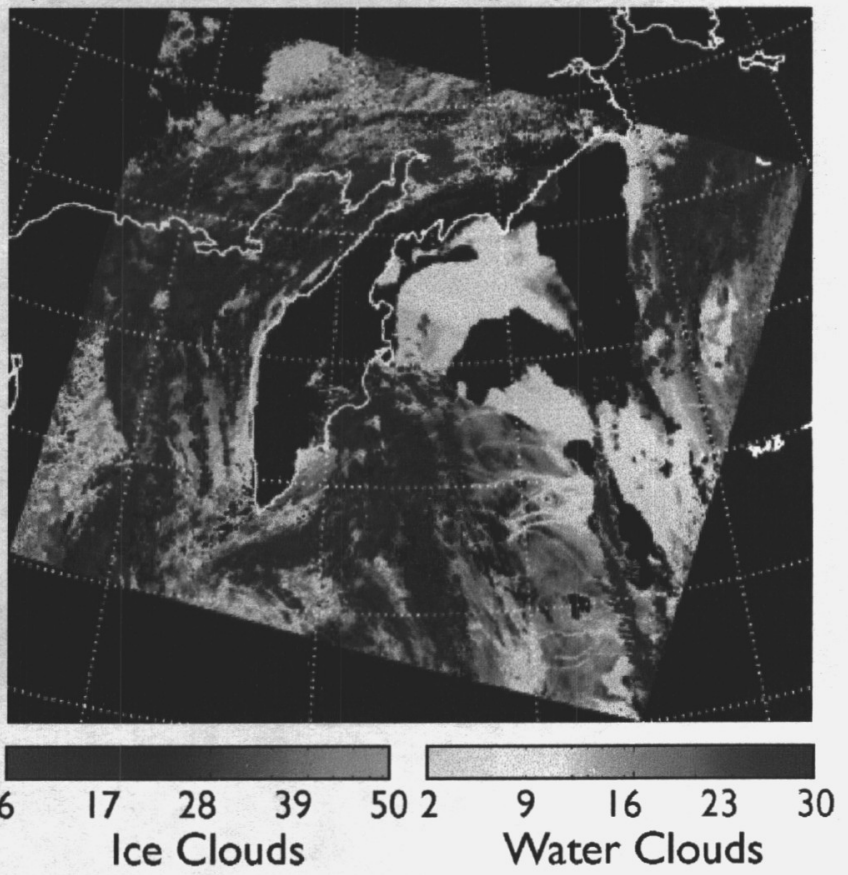

Fig. 8. Cloud properties over the western Pacific Ocean off the Kamchatka Peninsula on August 10, 2001. Panel (a) is a true color composite of one MODIS granule, showing marine stratocumulus clouds with ship tracks as well as upper level ice clouds. Panels (b) and (d) show the cloud optical thickness and effective radius derived from all cloudy pixels, where we have used a separate color bar to denote clouds processed as ice and water clouds. Panel (c) shows the cloud top pressure for all clouds in this scene. 

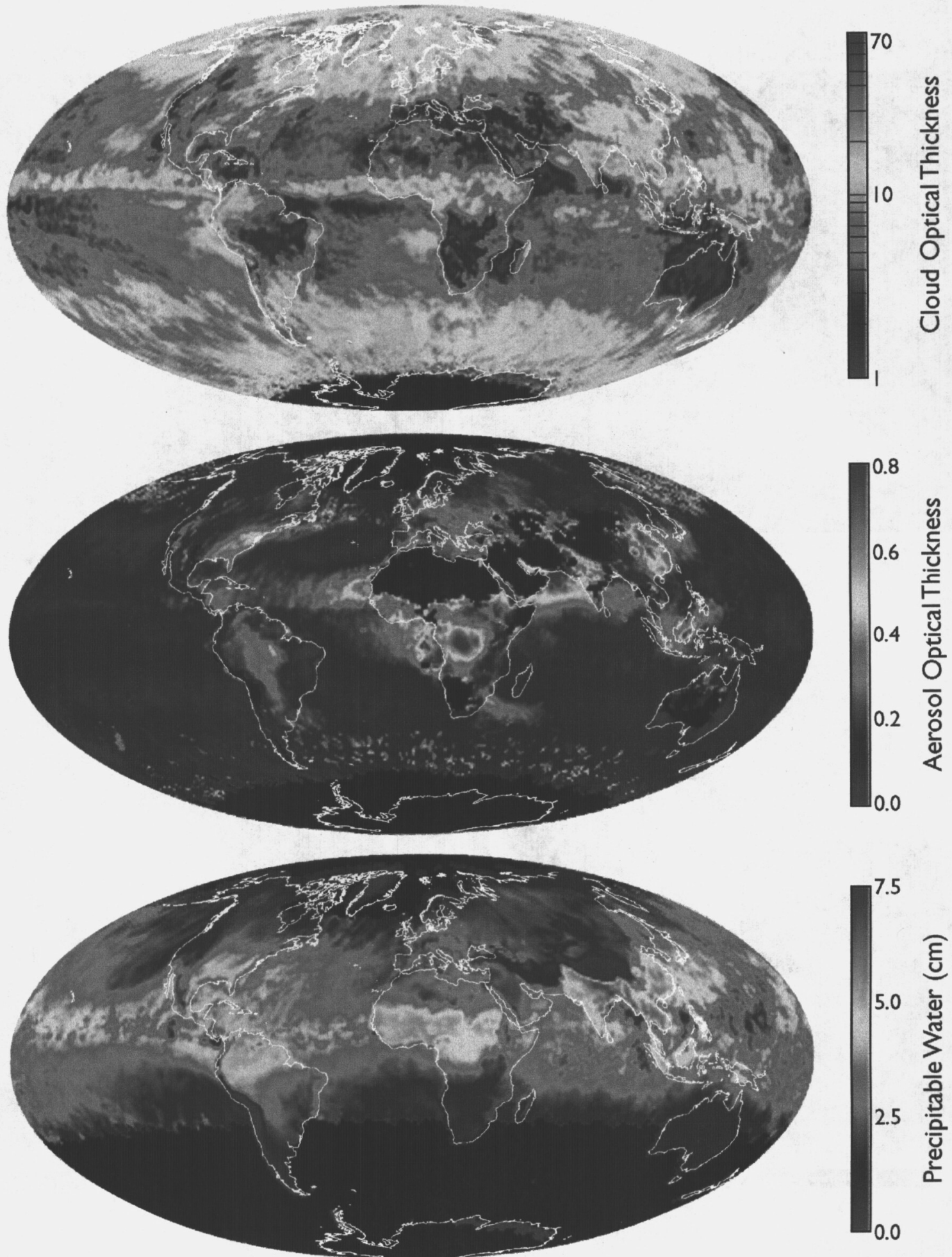

Fig. 9. Level-3 monthly averages of (a) cloud optical thickness, (b) aerosol optical thickness, and (c) near-infrared precipitable water for August 2001. These monthly products are produced at a $1^{\circ} \times 1^{\circ}$ latitude-longitude grid worldwide. 


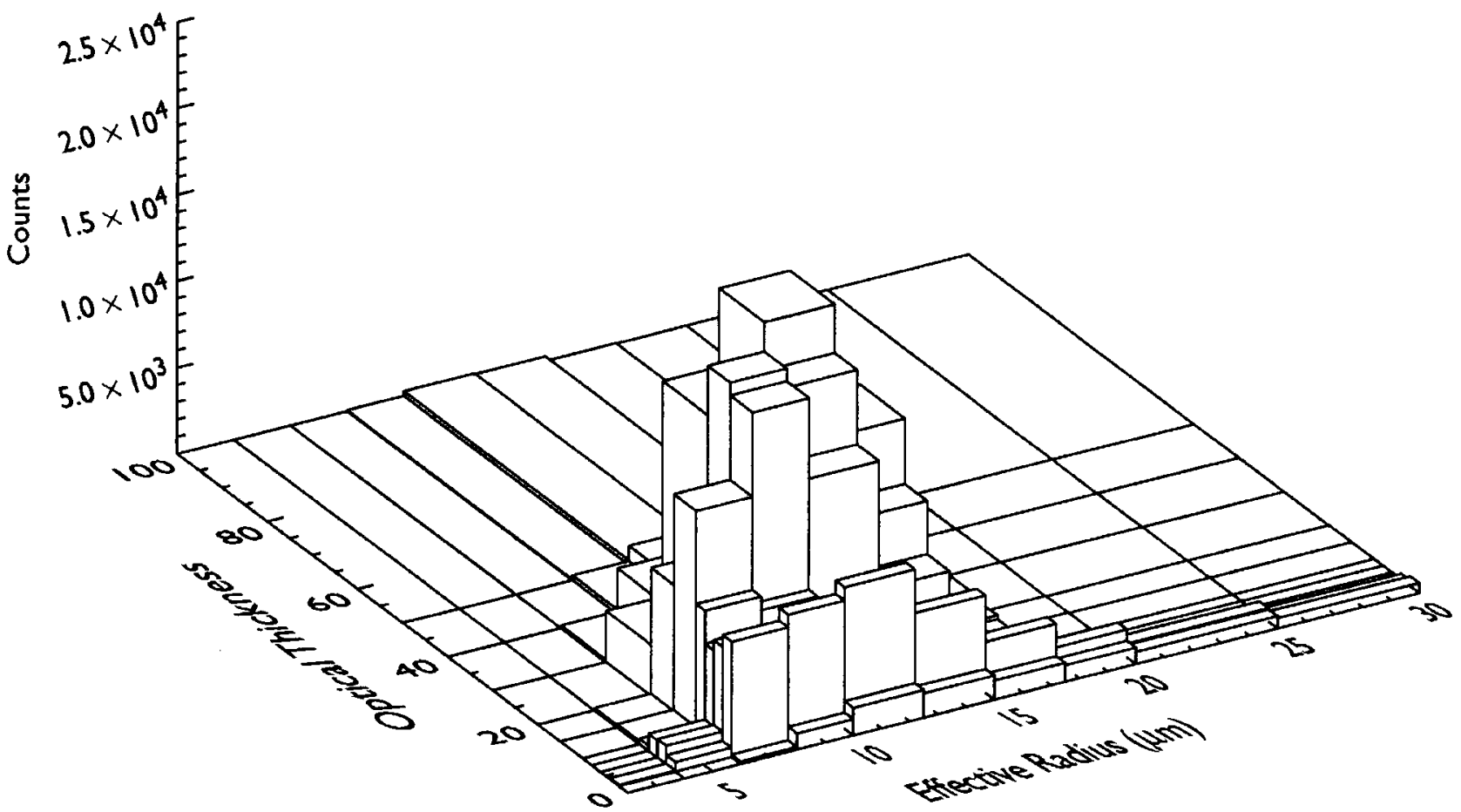

Fig. 10. Histogram of the joint probability of cloud optical thickness and effective radius derived from the Level-3 joint atmosphere product for August 2001 for a region off the coast of Peru and Chile bounded by $12^{\circ}-24^{\circ} \mathrm{S}$ and $68^{\circ}-80^{\circ} \mathrm{W}$. All liquid water cloud retrievals over ocean in this latitude-longitude box have been aggregated. The grid pattern reflects the bin boundaries in this Level- 3 data product. 